\title{
Investigation on Laser Welding of Al Ribbon to Cu Sheet: Weldability, Microstructure, and Mechanical and Electrical Properties
}

\author{
Won-Sang Shin ${ }^{1,+}$, Dae-Won Cho ${ }^{2,+}$, Donghyuck Jung ${ }^{1}$, Heeshin Kang ${ }^{3}$, Jeng O Kim ${ }^{3}$, Yoon-Jun Kim ${ }^{1, *(1)}$ \\ and Changkyoo Park ${ }^{3, *}$ \\ 1 Department of Materials Science and Engineering, Inha University, Incheon 22212, Korea; \\ sssjss@naver.com (W.-S.S.); ehdgur0628@naver.com (D.J.) \\ 2 Busan Machinery Research Center, Korea Institute of Machinery and Materials, Busan 46744, Korea; \\ dwcho@kimm.re.kr \\ 3 Laser and Electron Beam Application Department, Korea Institute of Machinery and Materials, \\ Daejeon 34103, Korea; khs@kimm.re.kr (H.K.); jokim@kimm.re.kr (J.O.K.) \\ * Correspondence: yoonjun@inha.ac.kr (Y.-J.K.); ck0421@kimm.re.kr (C.P.) \\ + Won-Sang Shin and Dae-Won Cho contributed equally to this work.
}

Citation: Shin, W.-S.; Cho, D.-W.; Jung, D.; Kang, H.; Kim, J.O.; Kim, Y.-J.; Park, C. Investigation on Laser Welding of Al Ribbon to Cu Sheet: Weldability, Microstructure, and Mechanical and Electrical Properties. Metals 2021, 11, 831. https://doi.org/ $10.3390 /$ met11050831

Academic Editor: Tomasz Kik

Received: 16 April 2021

Accepted: 17 May 2021

Published: 19 May 2021

Publisher's Note: MDPI stays neutral with regard to jurisdictional claims in published maps and institutional affiliations.

Copyright: (c) 2021 by the authors. Licensee MDPI, Basel, Switzerland. This article is an open access article distributed under the terms and conditions of the Creative Commons Attribution (CC BY) license (https:// creativecommons.org/licenses/by/ $4.0 /)$.

\begin{abstract}
The pulsed laser welding of $\mathrm{Al}$ ribbon to $\mathrm{Cu}$ sheet was investigated for the electrical interconnections in power electronic modules. The various experimental conditions with the different laser powers, scan speeds, and heat inputs were employed for obtaining the defect-free $\mathrm{Al} / \mathrm{Cu}$ joints. During the $\mathrm{Al} / \mathrm{Cu}$ laser welding, the intermetallic compounds were formed in the welding zone. An electron probe microanalyzer and transmission electron microscopy confirmed the phases of intermetallic compounds, which were found to be $\mathrm{Al}_{4} \mathrm{Cu}_{9}, \mathrm{Al}_{2} \mathrm{Cu}, \mathrm{AlCu}$, etc. The computational fluid dynamics simulation revealed that the Marangoni effect induced the circulation of the molten pool, resulting in the mixture of $\mathrm{Al}$ and $\mathrm{Cu}$ and the formation of swirl-like structures at the $\mathrm{Al} / \mathrm{Cu}$ joints. The tensile shear strengths and electrical resistances of the $\mathrm{Al} / \mathrm{Cu}$ joints were measured, and they showed a strong correlation with the welding area. A decrease in mechanical strength and an increase in electrical resistance were measured with increasing the welding area of $\mathrm{Al} / \mathrm{Cu}$ joints. Moreover, the process window for the defect-free $\mathrm{Al} / \mathrm{Cu}$ joints was developed, and the experimental conditions for $\mathrm{Al} / \mathrm{Cu}$ laser braze-welding were examined to minimize the intermetallic compounds formation at the $\mathrm{Al} / \mathrm{Cu}$ joints.
\end{abstract}

Keywords: laser welding; aluminum; copper; ribbon bonding; intermetallic compounds

\section{Introduction}

Electrical interconnections are crucial for packaging power electronic modules. The solid electrical interconnections with excellent mechanical and electrical properties are essential for preventing an electrical failure of power electronic modules. Resistance spot welding, brazing, soldering, and ultrasonic welding (USW) have been employed for the electrical interconnections. For both brazing and soldering, marginal deformation and residual stress are developed at the joints due to the low-temperature processes [1]. The filler alloys are essential for both processes to achieve the solid electrical contacts; thus, the joints are consisted of different metals in contact with one another. As a result, the joints can be susceptible to galvanic corrosion in the corrosive environments [2,3]. Moreover, only limited filler materials can be used in the specific joints because the affinity between base metals and filler materials should be considered [1]. USW is conducting with a low welding temperature and a short welding time, resulting in a relatively small deformation at the joints. Therefore, it is replacing the conventional bonding methods, especially for soft materials (e.g., $\mathrm{Al}, \mathrm{Cu}, \mathrm{Ag}$, $\mathrm{Au}$, and Ni) [4-6]. However, in the case of the USW process 
for $\mathrm{Cu}$, the $\mathrm{Sn}$ or $\mathrm{Ni}$ coating on $\mathrm{Cu}$ surface is necessary to prevent the deterioration of weldability owing to its tenacious surface oxide, which slows down the process and worsens the economic aspects for industrial applications $[7,8]$. Laser welding is a promising candidate for the electrical connections in power electronic modules owing to its characteristics of easy control, high precision, and remote processing. Its small heat-affected zone and deformation are expected to minimize damage at the electrical contacts [9-11]. In addition, no extra surface preparation is necessary for the laser welding.

The welding of dissimilar materials has been important in industrial applications. Moreover, it is becoming an essential technique in power electronic modules because a number of dissimilar joints are necessary for wire or ribbon bonding for the electrical connections, as shown in Figure $1[12,13]$. Among various combination of electrical contacts, $\mathrm{Al}$ and $\mathrm{Cu}$ are often considered as the crucial materials for the electrical connections because of their high electrical conductivity [14]. A dissimilar welding of $\mathrm{Al}$ and $\mathrm{Cu}$, however, promotes the formation of intermetallic compounds (IMCs), and concomitantly affects the mechanical and electrical properties of $\mathrm{Al} / \mathrm{Cu}$ joints. In general, the presence of IMCs inside $\mathrm{Al} / \mathrm{Cu}$ joints is detrimental to ductility and electrical resistance which promote an easy crack initiation and hampers electrical conductivity through weldment $[15,16]$. Therefore, the formation of IMCs should be avoided in order to obtain a robust $\mathrm{Al} / \mathrm{Cu}$ joint. Several studies have investigated the laser beam welding of $\mathrm{Al}$ and $\mathrm{Cu}$ sheets. A continuous-wave (CW) laser was employed for the $\mathrm{Al} / \mathrm{Cu}$ joints [17-23]. A number of cracks were observed in the welding zone due to the large heat input and significant IMCs formation [18,19]. A spatial oscillation of the CW laser beam has been shown to improve the welding quality of $\mathrm{Al} / \mathrm{Cu}$ joints. Fewer pores and cracks with smaller IMCs sizes were observed in the welding zone in comparison with those of the rectilinear $\mathrm{CW}$ laser beam [18-20]. A CW single mode fiber laser was utilized for the lap joining of $\mathrm{Al}$ and $\mathrm{Cu}$ sheets, and the solid $\mathrm{Al} / \mathrm{Cu}$ joints were obtained at a high welding speed (i.e., $50 \mathrm{~m} / \mathrm{min}$ ) by suppressing the IMCs formation [22]. Mai et al. [23] used a pulsed laser to achieve the dissimilar $\mathrm{Al} / \mathrm{Cu}$ welding. They revealed that the $\mathrm{Al} / \mathrm{Cu}$ weldability was strongly dependent on laser process parameters, and succeeded to attain the crack-free $\mathrm{Al} / \mathrm{Cu}$ joints at the scan speed of less than $100 \mathrm{~mm} / \mathrm{min}$.

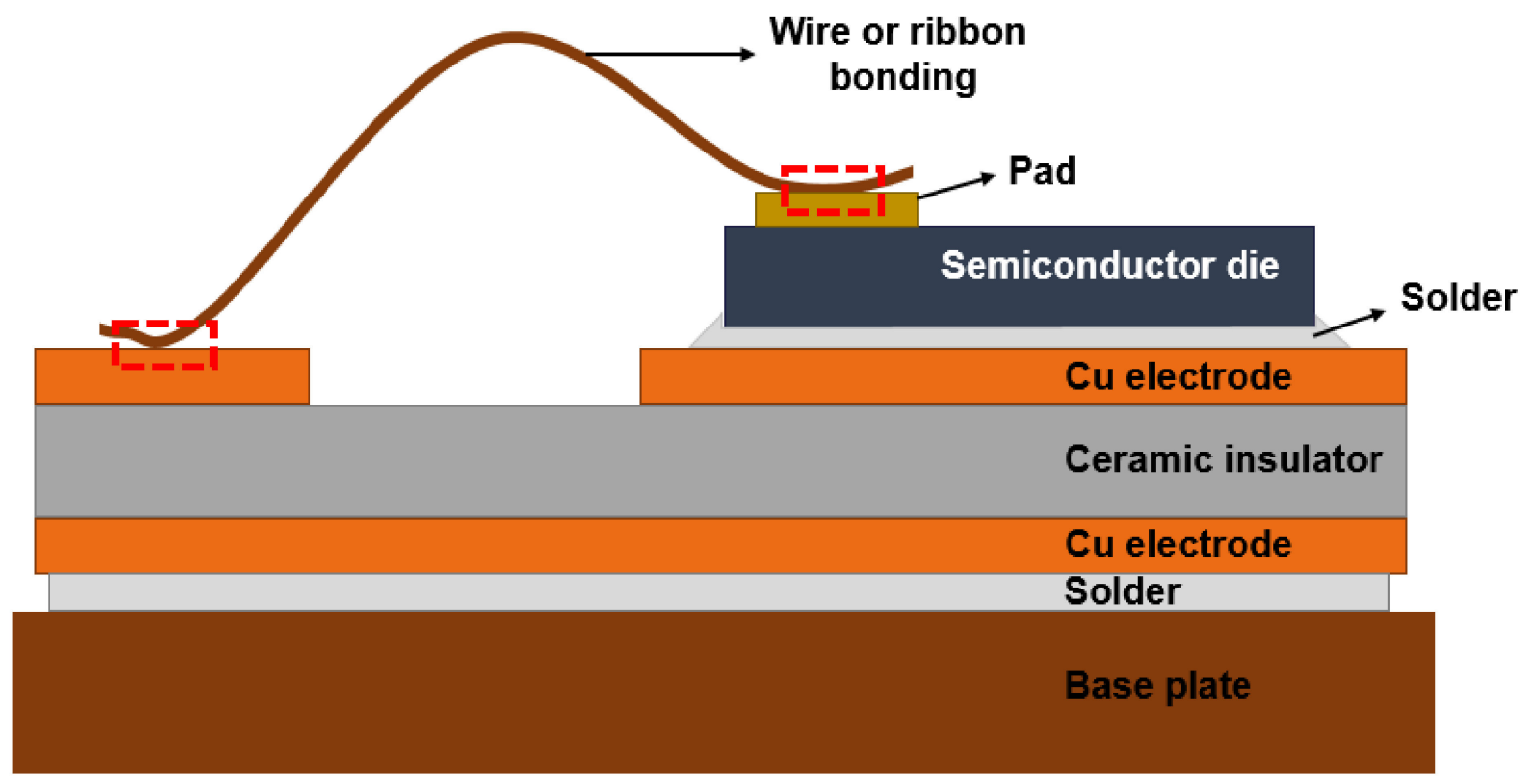

Figure 1. Schematic diagram of the insulated gate bipolar transistors (IGBT) power module. Red-dotted box indicated the electrical connections.

For the electrical interconnections, ribbon bonding has advantages over wire bonding, especially for power electronic modules that operate at a high frequency [24]. A high ratio of 
width to thickness of ribbon reduces the inductance and skin-effect loss, resulting in a lower high-frequency impedance than that of wire bonding [4]. To the best of our knowledge, only a few studies have investigated the dissimilar laser welding for ribbon bonding [25-27]. In this study, the pulsed laser welding of $\mathrm{Al}$ ribbon to $\mathrm{Cu}$ sheet was conducted under different experimental conditions to develop the process window for the solid $\mathrm{Al} / \mathrm{Cu}$ joints. Moreover, the experimental conditions for laser braze-welding were investigated to minimize the IMCs formation at the $\mathrm{Al} / \mathrm{Cu}$ joints. The microstructure of $\mathrm{Al} / \mathrm{Cu}$ joints was analyzed using an electron probe microanalyzer (EPMA), scanning electron microscopy (SEM) and transmission electron microscopy (TEM). The mechanical properties-such as microhardness and tensile shear strength along with electrical resistance of the $\mathrm{Al} / \mathrm{Cu}$ joints-were examined. Moreover, this study performed the numerical simulation to describe the molten pool flow for the $\mathrm{Al} / \mathrm{Cu}$ laser welding and verified the formation mechanism of swirl-like structures at the $\mathrm{Al} / \mathrm{Cu}$ joints.

\section{Materials and Methods}

\subsection{Materials and Experimental Setup for Laser Welding of $\mathrm{Al} / \mathrm{Cu}$}

The commercial-Cu sheet (purity: 99.99\%, Nilaco Co., Tokyo, Japan) and Al ribbon (purity: 99.9\%, Nilaco Co., Tokyo, Japan) were prepared in the dimensions, $20 \times 30 \times 1$ and $2 \times 45 \times 0.2 \mathrm{~mm}^{3}$, respectively, followed by cleaning ultrasonically in acetone for $2 \mathrm{~min}$. To make an overlap joint with an overlap length of $7 \mathrm{~mm}$, a firmly clamped $\mathrm{Al}$ ribbon was placed on the center of surface in the width and $7 \mathrm{~mm}$ in depth from the edge of $\mathrm{Cu}$ sheet as shown in Figure 2a. Figure $2 \mathrm{~b}$ shows an experimental setup for the laser system equipped with a quasi-CW fiber laser (YLS-600/6000-QCW-AC, IPG Photonics, Oxford, United States). Laser parameters, a central wavelength of $\lambda=1070 \mathrm{~nm}$, a pulse duration of $T_{p}=3 \mathrm{~ms}$, a repetition frequency of $f_{p}=100 \mathrm{~Hz}$, and a beam diameter of $200 \mu \mathrm{m}$ with super-Gaussian energy distribution were used, from which the laser beam quality factors $\left(M^{2}\right)$ were 11.7 and 12.1 for the horizontal direction and vertical direction, respectively. $\mathrm{The} \mathrm{Al} / \mathrm{Cu}$ specimens were placed on a computer-controlled motion system (Series O-M, Fanuc, Yamanashi, Japan) tilted $5^{\circ}$ to the normal direction of the laser head to prevent the damage of the laser system from reflected beam. A charge-coupled device camera was coaxially mounted on the laser head to find welding position on the specimens. The laser welding was performed using laser power range from 1800 to $3000 \mathrm{~W}$ varied in scan speed from 10 to $40 \mathrm{~mm} / \mathrm{s}$. The resultant heat input, dividing the laser power to the scan speed, was obtained in the range of 62.5 to $250 \mathrm{~J} / \mathrm{mm}$. The details of experimental conditions are listed in Table 1 . The laser welding of $\mathrm{Al}$ ribbon to $\mathrm{Cu}$ sheet was only achieved for the experimental conditions of the named specimens. During the laser welding, Ar gas was used as the shielding gas with a flow rate of $20 \mathrm{~L} / \mathrm{min}$.

(a)

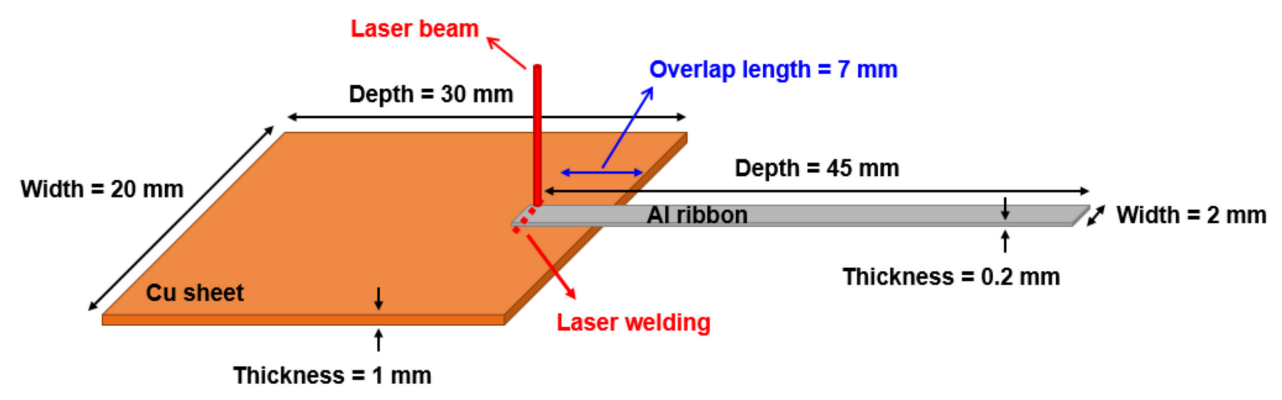

Figure 2. Cont. 
(b)

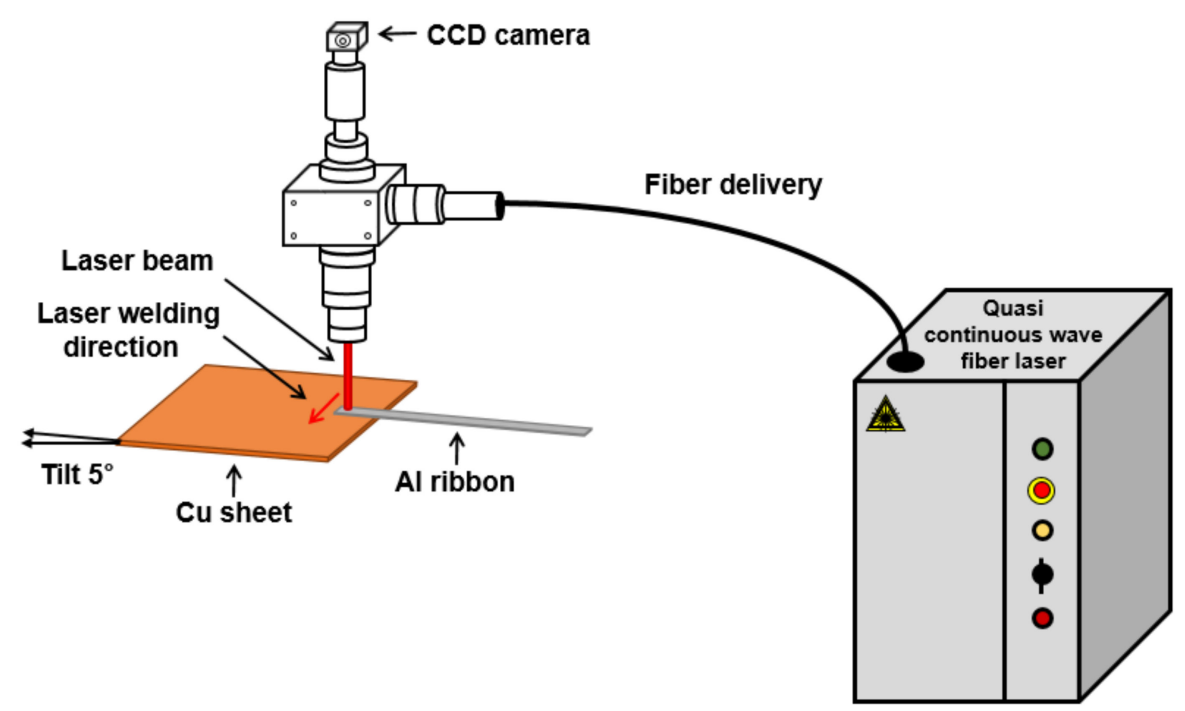

Figure 2. Experimental setups for the (a) Al/Cu overlap joint and (b) laser welding process.

Table 1. Experimental conditions for the laser welding of $\mathrm{Al}$ ribbon to $\mathrm{Cu}$ sheet. The $\mathrm{Al} / \mathrm{Cu}$ joints were only achieved for the experimental conditions of the named specimens.

\begin{tabular}{ccccc}
\hline Number & Specimen & Laser Power $(\mathbf{W})$ & Scan Speed $(\mathbf{m m} / \mathbf{s})$ & Heat Input $(\mathbf{J} / \mathbf{m m})$ \\
\hline 1 & - & 1800 & 20 & 90 \\
2 & - & 2100 & 10 & 210 \\
3 & - & 2100 & 15.4 & 136.5 \\
4 & - & 2100 & 20 & 105 \\
5 & - & 2200 & 20 & 110 \\
6 & - & 2300 & 10 & 172.5 \\
7 & - & 2300 & 13.3 & 172.5 \\
8 & $23 / 20$ & 2300 & 20 & 115 \\
9 & $23 / 28.6$ & 2500 & 28.6 & 80.5 \\
10 & - & 2500 & 10 & 250 \\
11 & - & 2500 & 13.3 & 187.5 \\
12 & $25 / 15.4$ & 2500 & 15.4 & 162.5 \\
13 & $25 / 20$ & 2500 & 20 & 125 \\
14 & $25 / 28.6$ & 2500 & 28.6 & 87.5 \\
15 & $25 / 40$ & 2700 & 40 & 62.5 \\
16 & $27 / 20$ & 2700 & 20 & 135 \\
17 & $27 / 28.6$ & 2700 & 28.6 & 94.5 \\
18 & $27 / 40$ & 2900 & 40 & 67.5 \\
19 & $29 / 20$ & 2900 & 20 & 145 \\
20 & $29 / 40$ & 3000 & 40 & 72.5 \\
21 & - & & 20 & 150 \\
\hline
\end{tabular}

\subsection{Metallographic Characterization}

In order to analyze the cross section of $\mathrm{Al} / \mathrm{Cu}$ joint, welded region on the specimen were cut into a half vertically (i.e., perpendicular to laser scan direction) using a low speed cutting wheel. Then, the specimens were fine-polished using 1 and $0.04 \mu \mathrm{m}$ colloidal silica suspensions. The cross-sectional macrostructure and microstructure of the $\mathrm{Al} / \mathrm{Cu}$ joints were characterized utilizing an optical microscopy (OM; ECLIPS MA 200, Nikon, Tokyo, Japan) and SEM (SU5000, Hitachi, Tokyo, Japan). Further quantitative analysis of the cross-section of the $\mathrm{Al} / \mathrm{Cu}$ joints was carried out using an EPMA (JXA-8500F, JEOL, Tokyo, Japan). The elemental distribution maps of $\mathrm{Al}$ and $\mathrm{Cu}$ were obtained at an acceleration voltage of $15 \mathrm{kV}$, a current of $50 \mathrm{nA}$, a step size of $4.9 \mu \mathrm{m}$, and a dwell time of $12 \mathrm{~ms}$. To 
investigate the IMCs formed inside the weldment, the EPMA line scans, at an acceleration voltage of $15 \mathrm{kV}$ and the dwell time of $800 \mathrm{~ms}$, were conducted at the center of $\mathrm{Al} / \mathrm{Cu}$ joints, and the measured relative atomic percentages of $\mathrm{Al}$ to $\mathrm{Cu}$ were used to identify the phases of IMCs. The TEM (Tecnai F20 G20, FEI, Lausanne, Switzerland) analysis was also performed to identify the phase of IMCs at the acceleration voltage of $200 \mathrm{kV}$. The TEM specimens were prepared at the center of $\mathrm{Al} / \mathrm{Cu}$ joints by a typical lift-out technique using a focused ion beam microscope (FIB; Hitachi-NX5000, Hitachi, Tokyo, Japan). To determine the welding area in $\mathrm{Al} / \mathrm{Cu}$ joints-hereinafter, assumed to be equivalent to the area of weldment-an image analysis program (iSolution DT x64, IMT i-Solution, Riverton, United States) was employed to find interface between IMCs and base metals where significant contrast change was observed in the SEM micrographs. The welding area was measured three times at the center of the $\mathrm{Al} / \mathrm{Cu}$ joints with $30 \mu \mathrm{m}$ apart for each measurement along the laser welding direction.

\subsection{Numerical Simulation Modeling}

The computational fluid dynamics (CFD) simulation was conducted to analyze the heat transfer and fluid flow in the molten pool during the laser welding of $\mathrm{Al}$ ribbon to $\mathrm{Cu}$ sheet. The governing equations for the CFD simulation of molten pool flow included the momentum conservation equation (Navier-Stokes equations), mass conservation equation, energy conservation equation, and volume of fluid equation [28-31]. Those equations were provided by a commercial software package, Flow-3D (Flow Science, Inc., Santa Fe, NM, USA). The material properties and variables used in the simulation are listed in Table 2. The mesh size was $0.02 \mathrm{~mm} / \mathrm{mesh}$, and the laser welding started at $10 \mathrm{~mm}$ along the $x$-direction, as shown in Figure 3.

Table 2. Nomenclatures and material properties used in the numerical simulation.

\begin{tabular}{|c|c|c|c|}
\hline Symbol & Nomenclature & Symbol & Nomenclature \\
\hline$\rho$ & Density $\left(2.8 \mathrm{~g} / \mathrm{cm}^{3}\right)$ & $P$ & Pressure on the free surface boundary \\
\hline$\vec{V}$ & Velocity vector & $R_{c}$ & Radius of the surface curvature \\
\hline$v$ & Kinematic viscosity $(0.013 \mathrm{gm} / \mathrm{cm} / \mathrm{s})$ & $\gamma(T)$ & Surface tension \\
\hline$f_{b}$ & Body force & $\gamma_{m}^{0}$ & $\begin{array}{l}\text { Surface tension at the melting temperature, } \\
\qquad 1000 \mathrm{dyne} / \mathrm{cm}\end{array}$ \\
\hline$h$ & Enthalpy & $T$ & Material temperature \\
\hline$\dot{h_{S}}$ & $\begin{array}{l}\text { Enthalpy source of droplet } \\
\text { Thermal conductivity }\end{array}$ & $\eta_{\text {laser }}$ & Laser heat efficiency, 0.075 \\
\hline$k$ & $\begin{array}{l}\mathrm{Al}: 1.87 \times 10^{7} \mathrm{erg} / \mathrm{s} / \mathrm{cm} / \mathrm{L} \\
\mathrm{Cu}: 3.37 \times 10^{7} \mathrm{erg} / \mathrm{s} / \mathrm{cm} / \mathrm{L}\end{array}$ & $P_{L}$ & Laser power $(\mathrm{W})$ \\
\hline$C_{p}$ & $\begin{array}{c}\text { Specific heat } \\
1.093 \times 10^{7} \mathrm{erg} / \mathrm{gm} / \mathrm{L}\end{array}$ & $A$ & $\begin{array}{l}\text { Surface tension gradient } \\
\text { Negative: }-0.3 \text { dyne } / \mathrm{cm} / \mathrm{T} \\
\text { Positive: } 0.3 \text { dyne } / \mathrm{cm} / \mathrm{T}\end{array}$ \\
\hline$h_{S}$ & Enthalpy of solid & $\sigma_{r}$ & Laser beam radius \\
\hline$h_{s l}$ & $\begin{array}{l}\text { Enthalpy between solid and liquid } \\
\qquad 3.89 \times 10^{9} \mathrm{~cm}^{2} / \mathrm{s}^{2}\end{array}$ & qlaser & Heat input from laser \\
\hline$T_{S}$ & Solidus temperature, $850 \mathrm{~K}$ & $q_{\text {conv }}$ & Heat loss from convection \\
\hline$T_{l}$ & Liquidus temperature, $775 \mathrm{~K}$ & $q_{\text {radi }}$ & Heat loss from radiation \\
\hline$\vec{n}$ & Normal vector to free surface & $q_{\text {evap }}$ & Heat loss from evaporation \\
\hline
\end{tabular}




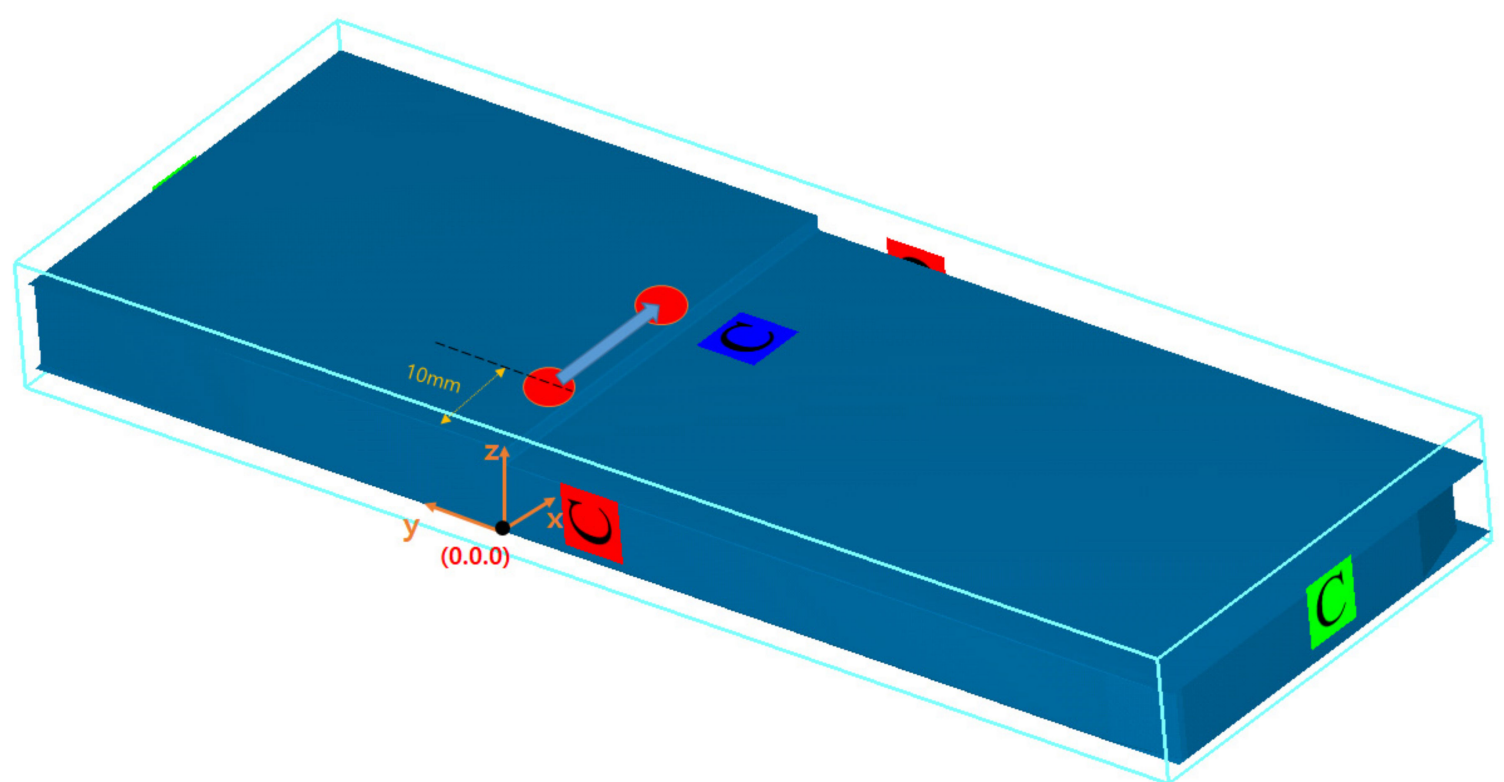

Figure 3. Schematic diagram of the numerical simulation domain and boundary conditions.

Momentum conservation equation

$$
\frac{\partial \vec{V}}{\partial t}+\vec{V} \cdot \nabla \vec{V}=-\frac{\nabla P}{\rho}+v \nabla^{2} \vec{V}+f_{b}
$$

Mass conservation equation

$$
\nabla \cdot \vec{V}=0
$$

Energy conservation equation

$$
\frac{\partial h}{\partial t}+\vec{V} \cdot \nabla h=\frac{1}{\rho} \nabla \cdot(k \nabla T)
$$

where

$$
\begin{array}{ll}
h=\rho_{s} C_{s} T & \left(T \leq T_{s}\right) \\
h=h\left(T_{s}\right)+h_{s l} \frac{T-T_{s}}{T_{l}-T_{s}} & \left(T_{s}<T \leq T_{l}\right) \\
h=h\left(T_{l}\right)+\rho_{l} C_{l}\left(T-T_{l}\right) & \left(T_{s}<T \leq T_{l}\right)
\end{array}
$$

Volume of fluid equation

$$
\frac{\partial F}{\partial t}+\nabla \cdot(\vec{V} F)=0
$$

\subsubsection{Boundary Conditions}

The laser heat source equations were included in the energy boundary condition [32]. The upper boundary region included the heat input from laser heat flux and the heat loss from convection, radiation, and evaporation. The upper boundary condition was applied as

$$
k \frac{\partial T}{\partial \vec{n}}=q_{\text {laser }}-q_{\text {conv }}-q_{\text {radi }}-q_{\text {evap }}
$$

Moreover, the pressure boundary for the free surface was applied as

$$
P=\frac{\gamma}{R_{c}}
$$




\subsubsection{Laser Heat Source Model}

The laser heat efficiency $\left(\eta_{\text {laser }}\right)$, laser power $\left(P_{L}\right)$, and laser beam radius $\left(\sigma_{r}\right)$ were considered to develop a super-Gaussian laser heat source model $\left(q_{\text {laser }}\right)$, as shown in Equation (8). The laser heat flux is applied to the top surface of the materials.

$$
q_{\text {laser }}=\frac{\eta_{\text {laser }} P_{L}}{\pi \sigma_{r}^{2}}
$$

\subsubsection{Surface Tension Model}

The keyhole mode was not generated during the laser welding due to a relatively low laser energy density. Therefore, the keyhole model was not considered in this study. However, the Marangoni flow driven by the surface tension gradient caused the molten pool flow (i.e., swirling) at the $\mathrm{Al} / \mathrm{Cu}$ joints. Thus, a surface tension model $(\gamma(T))$, function of temperature) was developed by considering the surface tension gradient $(A)$, melting point $\left(T_{s}\right)$, and surface tension at the melting point $\left(\gamma_{m}^{0}\right)[28-31]$.

$$
\gamma(T)=\gamma_{m}^{0}+A(T-T s)
$$

\subsection{Mechanical and Electrical Properties}

The microhardnesses of the base metals and $\mathrm{Al} / \mathrm{Cu}$ joints were measured using a nanoindentation test (Nanoindenter G200, KLA, Milpitas, CA, United States) with a Berkovich tip (U9701A-002, Keysight, Santa Rosa, CA, United States). The microhardness measurements were conducted at the cross-sectional area of the $\mathrm{Al} / \mathrm{Cu}$ joint perpendicular to the laser welding direction. The measurements were performed at an interval of $3 \mu \mathrm{m}$ with a load of $0.1 \mathrm{gf}$ holding for $10 \mathrm{~s}$ and a loading time of $15 \mathrm{~s}$. All the microhardness measurements were performed three times to obtain the average microhardness. The mechanical strength of the $\mathrm{Al} / \mathrm{Cu}$ joints was measured by the tensile shear tests ( 5848 series, INSTRON, Norwood, MA, United States) at a crosshead speed of $3 \mathrm{~mm} / \mathrm{min}$. All the tensile shear tests were repeated five times, and the average tensile shear strengths were obtained. A four-point probe meter (RM3545, HIOKI, Nagano, Japan) with two probes for carrying the current and two probes for sensing the voltage was used to measure the electrical resistance of the $\mathrm{Al} / \mathrm{Cu}$ joints [33]. The measured electrical resistance was considered to be $R=R_{c u}+R_{\text {weld }}+R_{A l}$, as shown in Figure 4. It was assumed that the electrical resistances of $\mathrm{Al}$ and $\mathrm{Cu}$ were not influenced by the laser welding process but affected only by the electrical resistance of the weldment. All the electrical resistance measurements were performed five times, and the average electrical resistances were obtained.

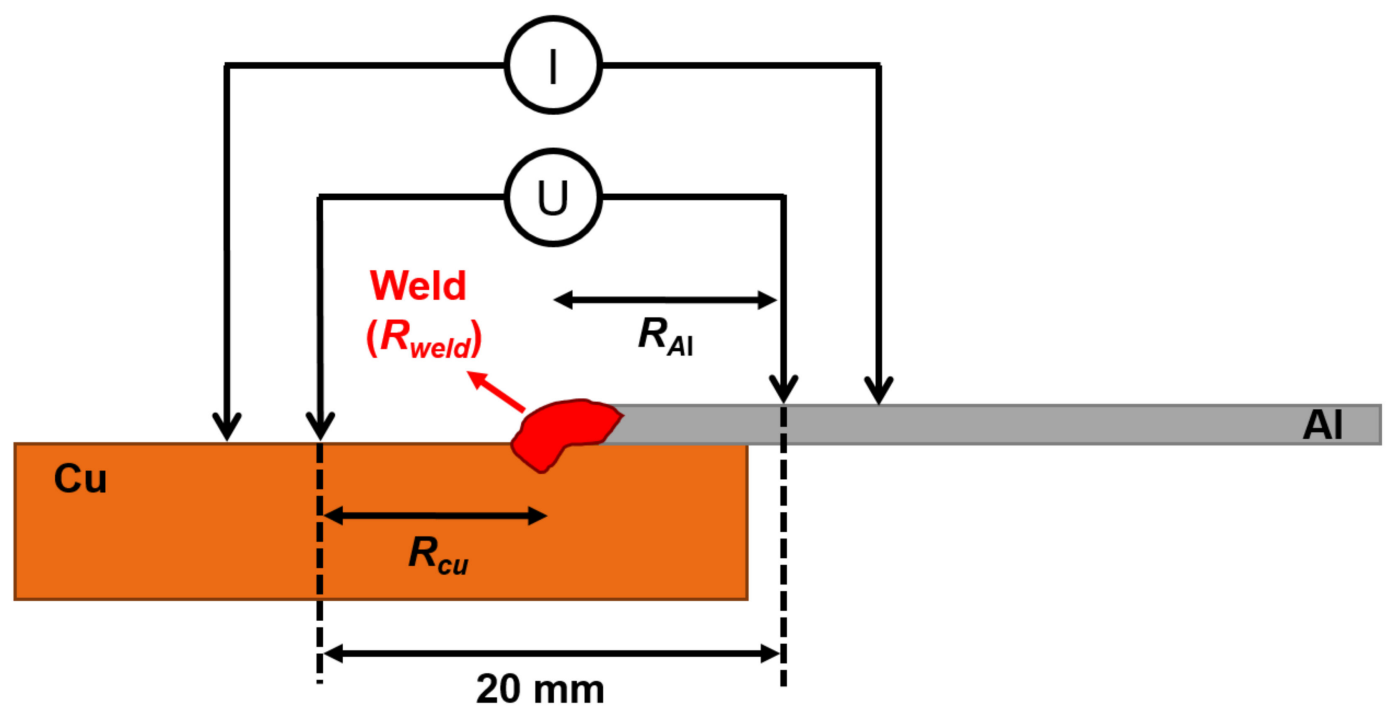

Figure 4. Experimental setup for the four-point electrical resistance measurement. 


\section{Results and Discussion}

Figure 5 shows the cross-sectional OM image of the $\mathrm{Al} / \mathrm{Cu}$ joints in parallel to the laser welding direction at a laser power of $2300 \mathrm{~W}$ and a scan speed of $20 \mathrm{~mm} / \mathrm{s}$ (i.e., a specimen of 23/20). A mixture of $\mathrm{Al}$ and $\mathrm{Cu}$ can be observed in the welding zone (dark gray and black areas with red arrows), which is the intermetallic compounds. The formation of $\mathrm{Al} / \mathrm{Cu} \mathrm{IMCs}$ is known to cause the deterioration of mechanical and electrical properties of the $\mathrm{Al} / \mathrm{Cu}$ joints. Therefore, the IMCs formation should be minimized to obtain the solid electrical connections. In this study, the minimization of IMCs formation is considered as the primary requirement for the laser welding of $\mathrm{Al}$ ribbon to $\mathrm{Cu}$ sheet.

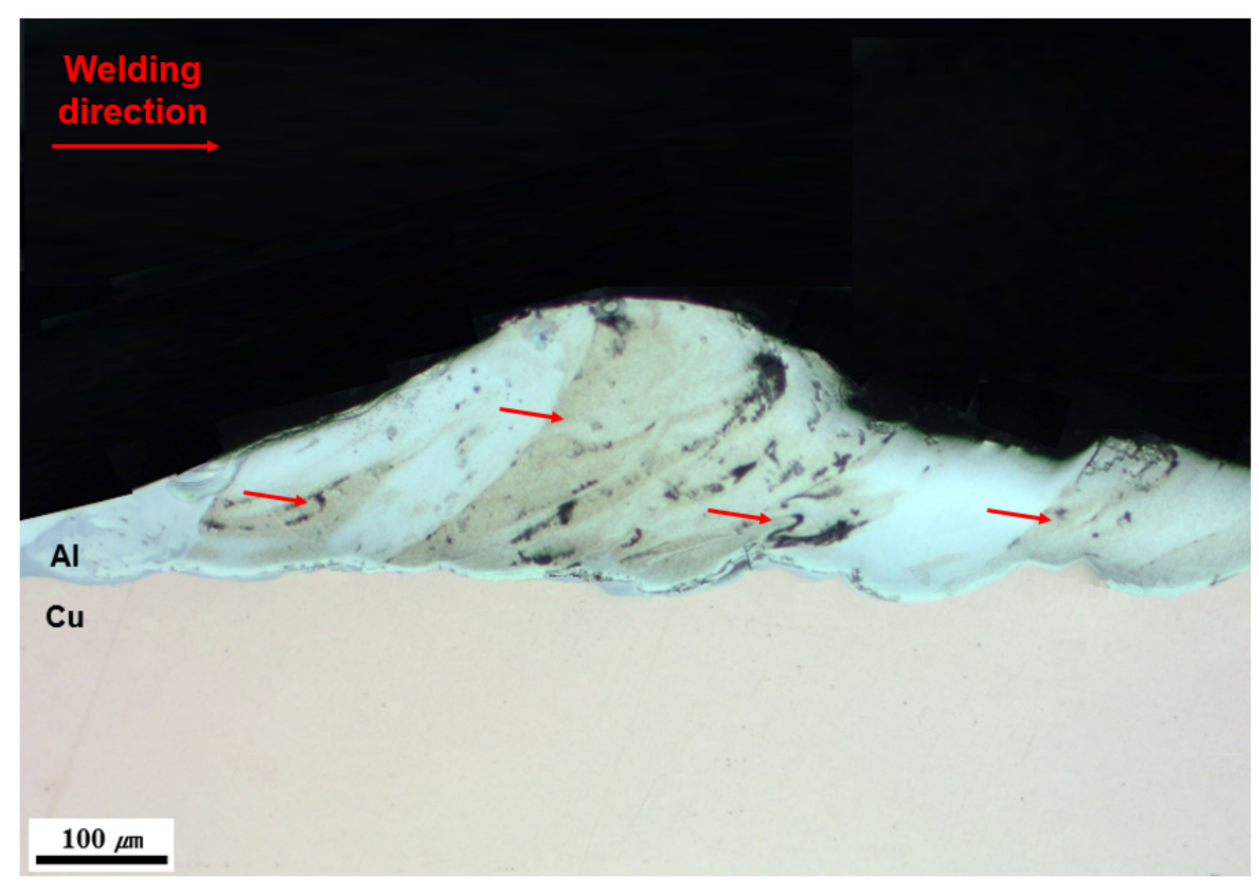

Figure 5. Cross-sectional $\mathrm{OM}$ image of the $\mathrm{Al} / \mathrm{Cu}$ joints in parallel to the laser welding direction. The laser power and scan speed were set at $2300 \mathrm{~W}$ and $20 \mathrm{~mm} / \mathrm{s}$, respectively.

\subsection{Microstructures}

Figure 6 shows the cross-sectional SEM images of the $\mathrm{Al} / \mathrm{Cu}$ joints, and corresponding EPMA element mapping of Al and Cu for the (a) 23/20, (b) 25/28.6, (c) 25/15.4, and (d) $27 / 20$. For every sample, the mixture of $\mathrm{Al}$ and $\mathrm{Cu}$ (i.e., IMCs) induced the swirllike structures in the welding zones, and those can be identified in the SEM images and elemental distribution maps. In the case of the 23/20 and 25/28.6, in Figure 6a,b, shallow welding depths in the $\mathrm{Cu}$ sheet were observed with no weld defects. The deepest welding depth was approximately $25 \mu \mathrm{m}$ for both $23 / 20$ and $25 / 28.6$, which can be considered as the laser braze-welded $\mathrm{Al} / \mathrm{Cu}$ joints [21]. Similar results were obtained for the 23/28.6 and 25/40. Small $\mathrm{Al}$ and $\mathrm{Cu}$ diffusions were observed in the elemental distribution maps, thus, the simple swirl-like structures with small welding zones were developed for the $23 / 20$ and $25 / 28.6$. On the contrary, significantly deep welding depths in the Cu sheet with 200 and $175 \mu \mathrm{m}$ were observed for the 25/15.4 (Figure 6c) and 27/20 (Figure 6d), respectively. Moreover, relatively complex swirl-like structures and large welding zones were developed with multiple cracks and voids compared with those of the 23/20 and 25/28.6. The significant difference in the melting temperatures and thermal expansion coefficients of $\mathrm{Al}$ and $\mathrm{Cu}$ can induce the residual thermal stresses at the $\mathrm{Al} / \mathrm{Cu}$ joints during the solidification [23,34]. For the 25/15.4 and 27/20, an application of excessive heat input during the $\mathrm{Al} / \mathrm{Cu}$ laser welding process induced the turbulent mixture of $\mathrm{Al}$ and $\mathrm{Cu}$, resulting in the formation of complex swirl-like structures with large welding zones [33]. Accordingly, the great residual stress may be created at the $\mathrm{Al} / \mathrm{Cu}$ joint, causing 
the development of cracks and voids at the welding zones. Similar results were obtained for the $29 / 20$ and $29 / 40$.

(a)

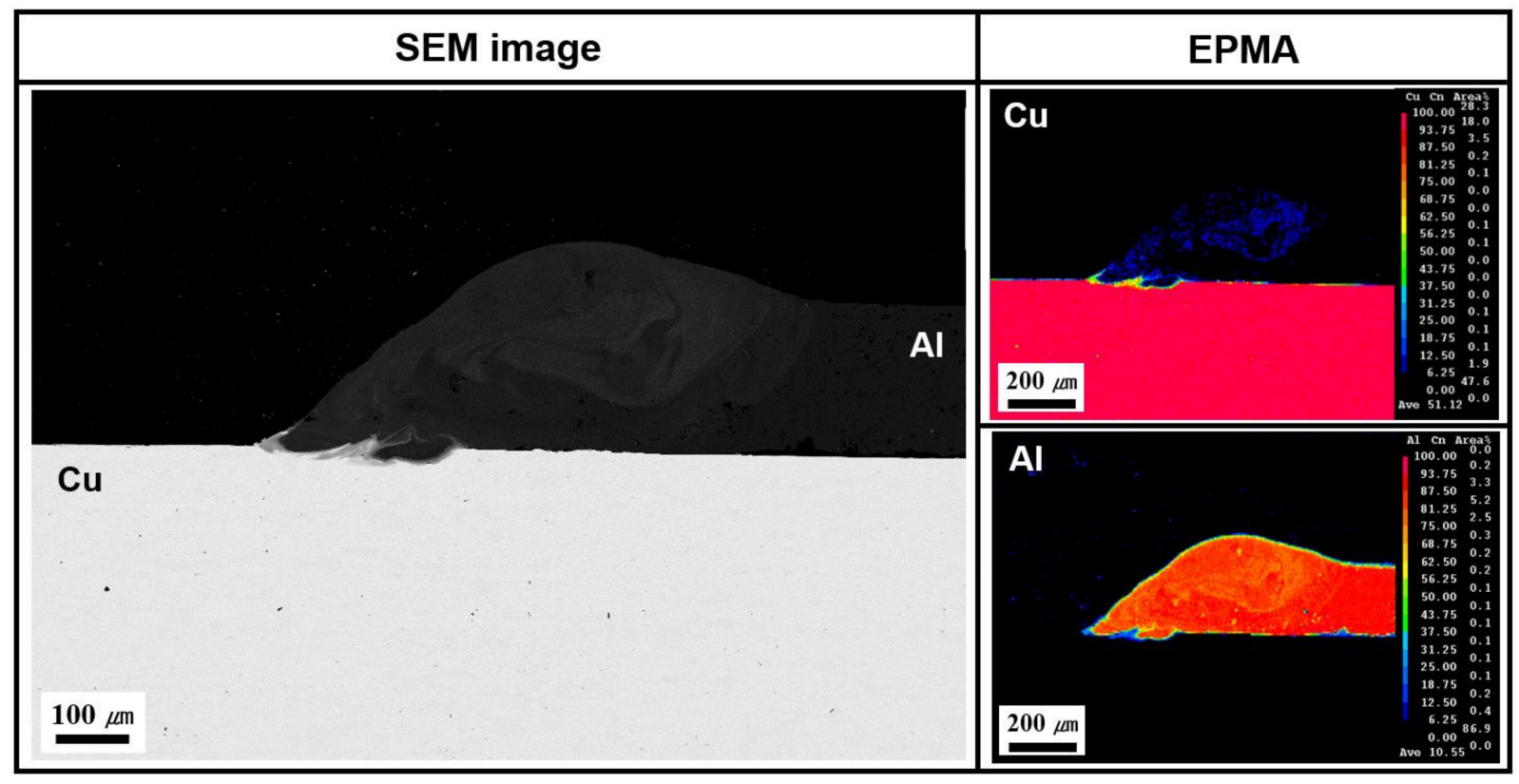

(b)

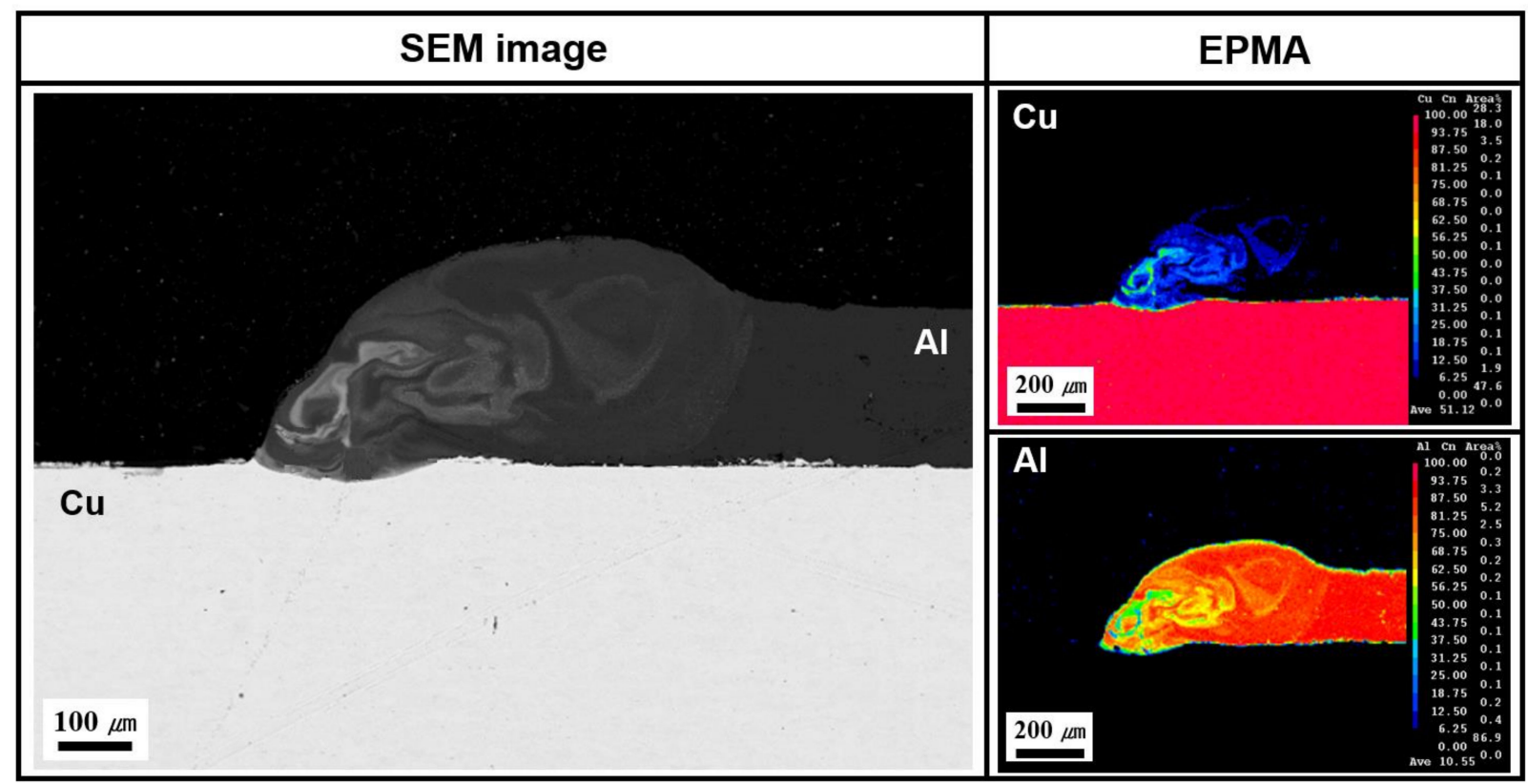

Figure 6. Cont. 
(c)

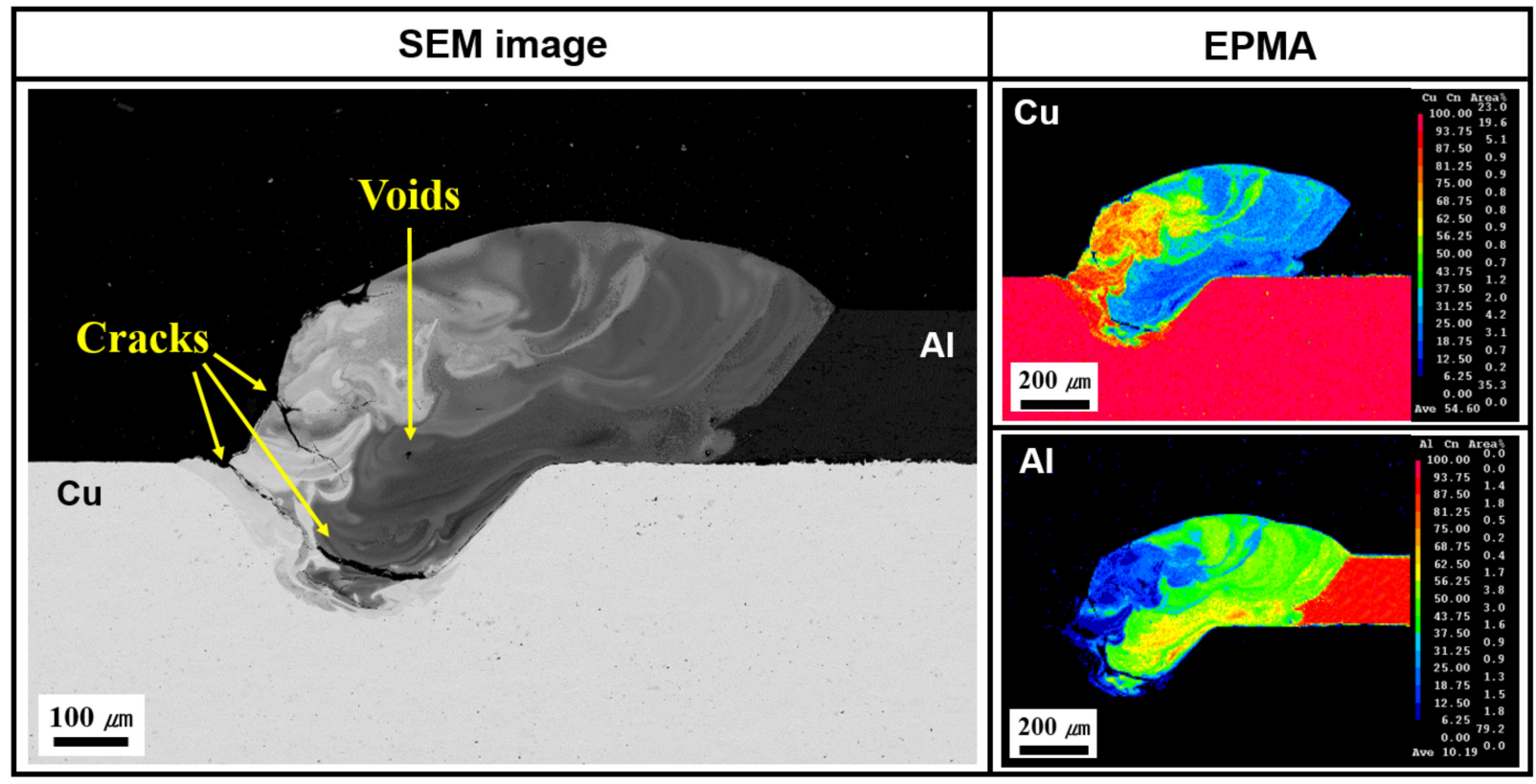

(d)

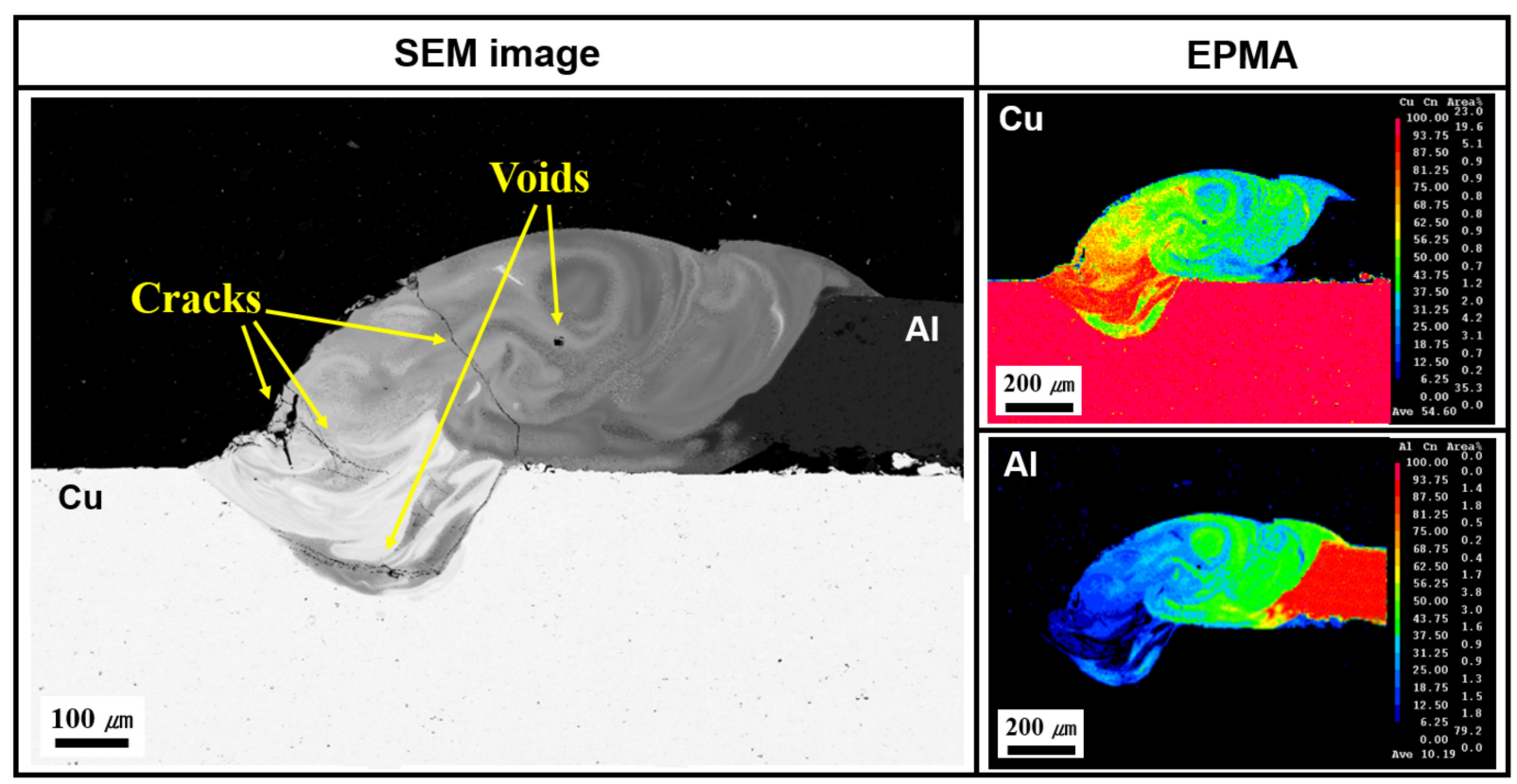

Figure 6. Cross-sectional SEM image and elemental distribution mapping of $\mathrm{Al}$ and $\mathrm{Cu}$ elements for the (a) 23/20, (b) 25/28.6, (c) 25/15.4, and (d) $27 / 20$.

Figure 7 shows the EPMA line scan analysis for $\mathrm{Al}$ and $\mathrm{Cu}$ elements in the welding zones of (a) 23/20 and (b) 25/15.4. The atomic percentages of $\mathrm{Al}$ and $\mathrm{Cu}$ were confirmed along the line scans, and these values were used to estimate the possible phases of IMCs. In the case of the $23 / 20$, relatively simple $\mathrm{Al}$ and $\mathrm{Cu}$ atomic percentage profiles were obtained owing to a low mixture of $\mathrm{Al}$ and $\mathrm{Cu}$. The EPMA analysis revealed that $\mathrm{AlCu}_{2}, \mathrm{Al}_{8} \mathrm{Cu}$, and $\mathrm{AlCu}_{8}$ were formed at the welding zone during the $\mathrm{Al} / \mathrm{Cu}$ laser welding. On the contrary, in the case of the 25/15.4, a large fluctuation of $\mathrm{Al}$ and $\mathrm{Cu}$ atomic percentage profiles was detected along the line scan owing to a turbulent mixture of $\mathrm{Al}$ and $\mathrm{Cu}$. Various IMCs were developed in the welding zone, which were confirmed as $\mathrm{Al}_{2} \mathrm{Cu}_{3}, \mathrm{Al}_{3} \mathrm{Cu}_{2}, \mathrm{AlCu}_{3}, \mathrm{Al}_{3} \mathrm{Cu}$, 
$\mathrm{AlCu}$, and $\mathrm{Al}_{8} \mathrm{Cu}$. Table 3 lists the developed IMCs phases for the 23/20, 25/28.6, 25/15.4, and $27 / 20$. More various types of IMCs were likely to be developed in the welding zone with increasing the heat input during laser welding.

(a)

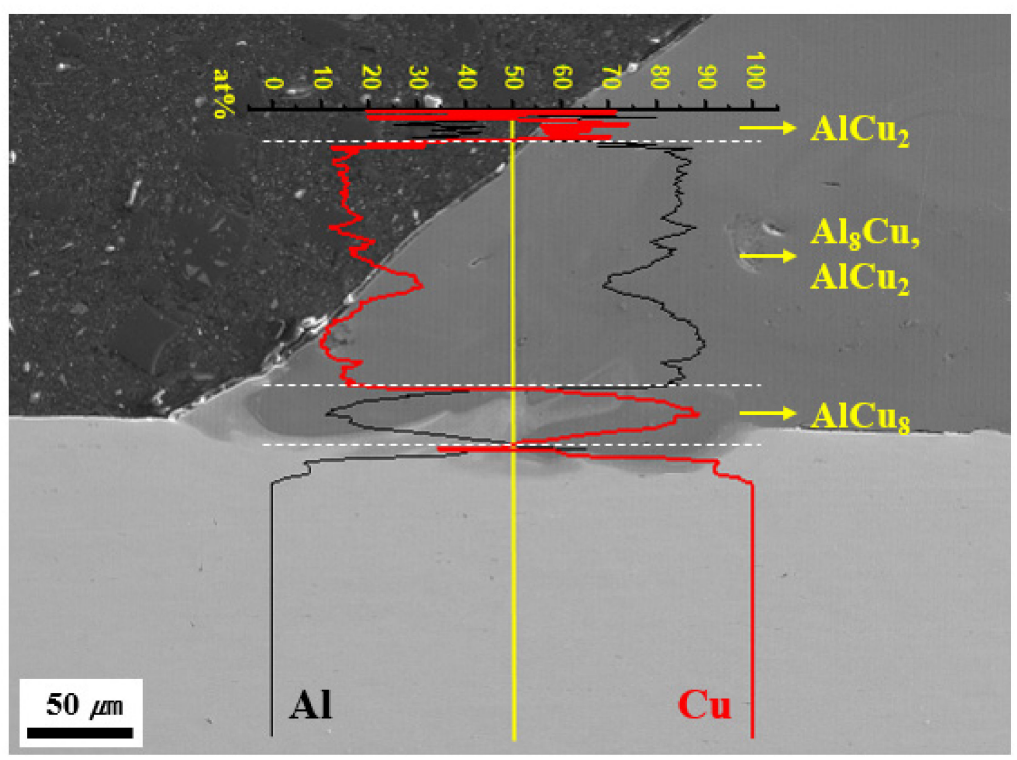

(b)

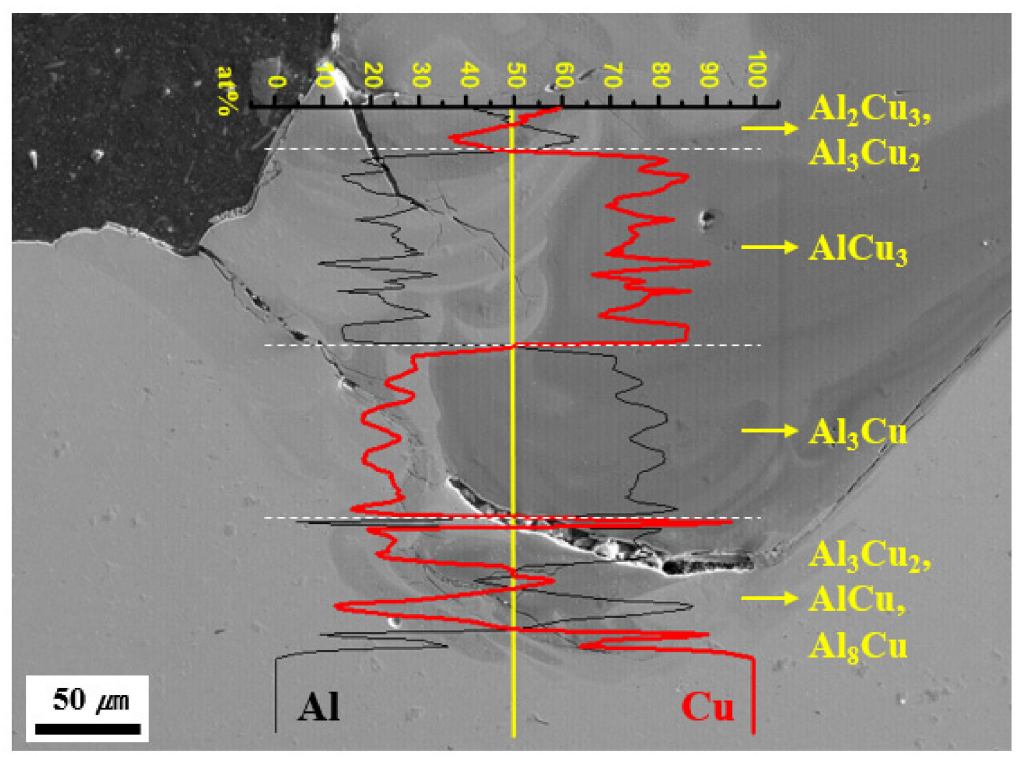

Figure 7. EPMA line scan analysis and identification of the IMCs for the (a) $23 / 20$ and (b) $25 / 15.4$.

Table 3. Formed intermetallic compounds during the dissimilar $\mathrm{Al} / \mathrm{Cu}$ laser welding.

\begin{tabular}{cc}
\hline Specimen & Intermetallic Compounds \\
\hline $23 / 20$ & $\mathrm{AlCu}_{2}, \mathrm{Al}_{8} \mathrm{Cu}, \mathrm{AlCu}_{8}$ \\
$25 / 28.6$ & $\mathrm{Al}_{2} \mathrm{Cu}_{1} \mathrm{Al}_{4} \mathrm{Cu}_{9}, \mathrm{Al}_{13} \mathrm{Cu}, \mathrm{Al}_{9} \mathrm{Cu}_{11}$ \\
$25 / 15.4$ & $\mathrm{Al}_{2} \mathrm{Cu}_{3}, \mathrm{Al}_{3} \mathrm{Cu}_{2}, \mathrm{AlCu}_{3}, \mathrm{Al}_{3} \mathrm{Cu}, \mathrm{AlCu}_{1} \mathrm{Al}_{8} \mathrm{Cu}$ \\
$27 / 20$ & $\mathrm{Al}_{2} \mathrm{Cu}_{3}, \mathrm{AlCu}_{2}, \mathrm{AlCu}_{3}, \mathrm{AlCu}_{7}, \mathrm{AlCu}$ \\
\hline
\end{tabular}

Further IMCs identification was performed using the TEM analysis at two locations in the swirl-like structure of 25/28.6, as shown in Figure 8a. Figure 8b shows the TEM 
bright-field image at the location (1) in Figure 8a. The microstructure was consisted of the $\mathrm{Al}$ primary phase and $\mathrm{Al}_{2} \mathrm{Cu}$ eutectic phase. The selected area electron diffraction (SAED) pattern on the right inset in Figure $8 \mathrm{~b}$ was taken at the primary phase, and it was analyzed as an Al-rich face-centered cubic (FCC) structure with a lattice parameter of $\mathrm{a}=4.046 \AA$ at the zone axis of [011] . Similarly, the left inset in Figure $8 \mathrm{~b}$ was identified as the $\theta$-tetragonal $\mathrm{Al}_{2} \mathrm{Cu}$ with the lattice parameters of $\mathrm{a}=6.057 \AA$ and $\mathrm{c}=4.824 \AA$ at the zone axis of [001] [35,36]. Figure $8 \mathrm{c}$ shows the TEM bright-field image at the location (2) in Figure 8a. The SAED pattern was analyzed at the black precipitate (marked with the red circle), confirmed the simple cubic $\mathrm{Al}_{4} \mathrm{Cu}_{9}$ with a lattice parameter of $\mathrm{a}=8.72 \AA$ at the zone axis of [125] [35]. It is noteworthy that $\mathrm{Al}_{2} \mathrm{Cu}$ and $\mathrm{Al}_{4} \mathrm{Cu}_{9}$ are the brittle IMCs in the $\mathrm{Al}-\mathrm{Cu}$ binary system $[36,37]$. The EMPA and TEM analyses revealed that the $\mathrm{Al} / \mathrm{Cu}$ joints were consisted of various types of the $\mathrm{Al} / \mathrm{Cu} \mathrm{IMCs}$, which were likely to form cracks in the welding zone [38].

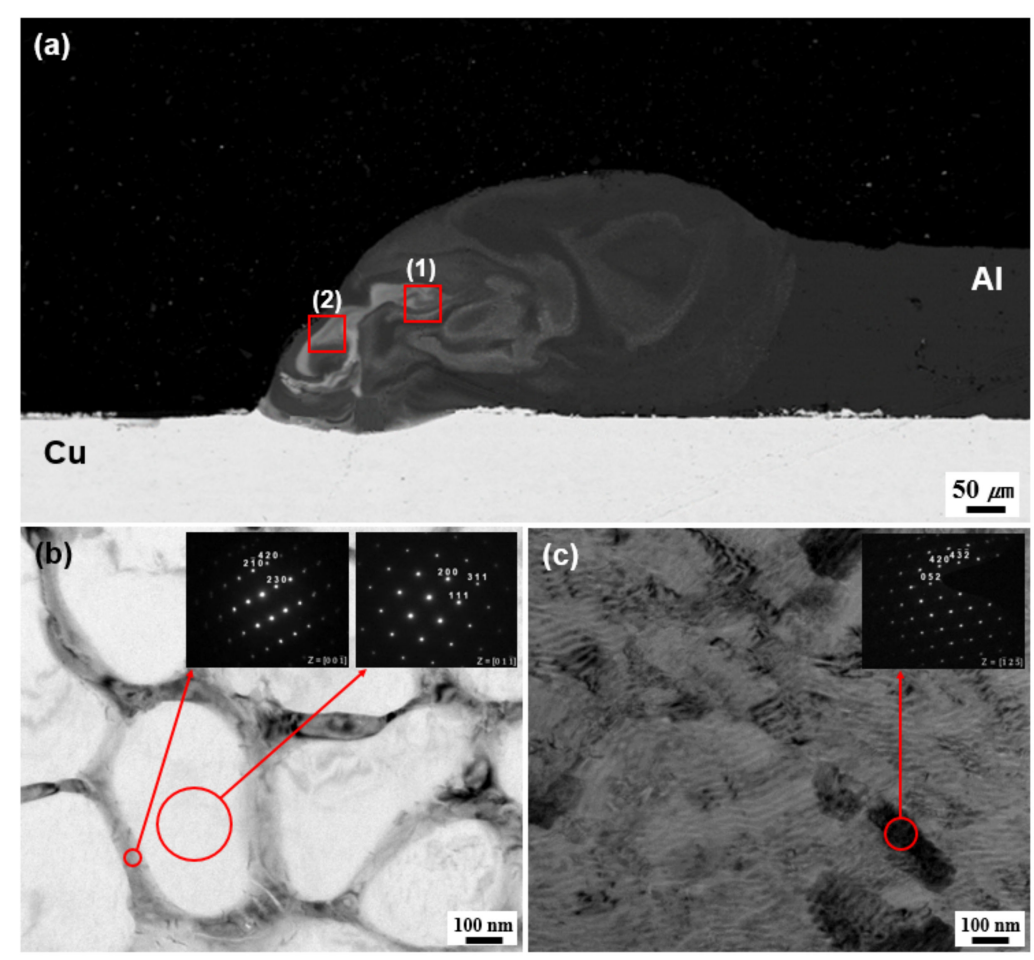

Figure 8. TEM analysis for the 25/28.6. (a) Indicating the location of TEM analysis in SEM image of the welding zone. (b) TEM bright-field image and SAED pattern insets, examined at the location (1) in figure (a), confirmed $\mathrm{Al}$-rich phase (white globular shape) and $\mathrm{Al}_{2} \mathrm{Cu}$ eutectic phase (gray region), and (c) TEM bright-field image and SAED pattern inset of $\mathrm{Al}_{4} \mathrm{Cu}_{9}$, examined at the location (2) in figure (a).

\subsection{Numerical Simulation Results}

Four different numerical simulations were conducted to examine the molten pool behavior during the laser welding of $\mathrm{Al}$ ribbon to $\mathrm{Cu}$ sheet in terms of the heat input, surface tension, and surface tension gradient. The simulation conditions are listed in Table 4.

Table 4. Details of the numerical simulation.

\begin{tabular}{|c|c|c|c|c|}
\hline Case & Laser Power (W) & Scan Speed $(\mathrm{mm} / \mathrm{s})$ & $\begin{array}{c}\text { Surface Tension at Melting } \\
\text { Temperature (dyne/cm) }\end{array}$ & $\begin{array}{c}\text { Surface Tension Gradient } \\
\text { (dyne/cm/K) }\end{array}$ \\
\hline 1 & 2300 & 20 & 1000 & -0.2 \\
\hline 2 & 2500 & 15.4 & 1000 & -0.2 \\
\hline 3 & 2500 & 15.4 & 1000 & 0.2 \\
\hline 4 & 2500 & 15.4 & - & - \\
\hline
\end{tabular}


Figure 9 shows the numerical simulation results with the temperature profile and molten pool flow as a function of the welding time for four different cases. Figure 9a (Case 1) shows the simulation result for the $23 / 20$. The molten pool flow dominantly occurred in $\mathrm{Al}$, and only a marginal weld penetration was observed in the $\mathrm{Cu}$ sheet. This result well coincides with the SEM and EPMA analyses (Figure 6a), which show the laser braze-welding with a low mixture of $\mathrm{Al}$ and $\mathrm{Cu}$ owing to a relatively low heat input (i.e., $115 \mathrm{~J} / \mathrm{mm}$ ). Figure $9 \mathrm{~b}$ (Case 2 ) describes the simulation result for the 25/15.4. At the welding time of $0.012 \mathrm{~s}$, the outward molten pool flow was observed at the top surface of $\mathrm{Al}$ due to the negative surface tension gradient. Moreover, the counter-clockwise circulation occurred from the $\mathrm{Al}$ ribbon to the $\mathrm{Cu}$ sheet, leading to a deep weld penetration in the $\mathrm{Cu}$ sheet. In the case of the $25 / 15.4$, a relatively large heat input of $162.5 \mathrm{~J} / \mathrm{mm}$ caused the rigorous molten pool flow, resulting in the turbulent mixture of $\mathrm{Al}$ and $\mathrm{Cu}$ and the formation of various IMCs, as shown in Figures $6 \mathrm{c}$ and $7 \mathrm{~b}$. Figure $9 \mathrm{c}$ (Case 3) shows the simulation result with the positive surface tension gradient for the 25/15.4. The circulation of the molten pool occurred through the center of the weld pool. As a result, a bumpy surface of the molten pool was developed. This simulation result was not accorded with the experimental result. As shown in the cross-sectional SEM images (Figure 6), the smooth surface of $\mathrm{Al} / \mathrm{Cu}$ joints was obtained due to the wetting of molten materials during the laser welding process. Figure $9 \mathrm{~d}$ (Case 4 ) describes the simulation result with no surface tension and surface tension gradient for the 25/15.4. It showed a significantly different result from the experimental result. The molten pool flowed downward due to gravity and rose at the weld toe. Moreover, no wetting of molten materials was observed. Consequently, the numerical simulation results revealed that the heat input, surface tension, and surface tension gradient were crucial factors determining the molten pool behavior. The applied heat input affected the size of the molten pool and weld penetration in the $\mathrm{Cu}$ sheet. The larger size of the molten pool with deeper weld penetration was achieved with increasing the heat input. Moreover, the surface tension gradient induced the Marangoni flow at the molten pool. This fluid flow caused a mixing of $\mathrm{Al}$ and $\mathrm{Cu}$, resulting in the development of swirl-like structures and IMCs at the $\mathrm{Al} / \mathrm{Cu}$ joints.

\subsection{Microhardness and Tensile Shear Strength}

Figure 10 shows the measured microhardness as a function of the distance for the 23/20. The average microhardnesses of $\mathrm{Cu}$ and $\mathrm{Al}$ were found to be 2.3 and $2.0 \mathrm{GPa}$, respectively. These values significantly increased to $12.7 \mathrm{GPa}$ at the $\mathrm{Al} / \mathrm{Cu}$ joint because of the formation of the IMCs. Hug et al. [38] also reported similar results: the microhardness values of the base metals (approximately $1 \mathrm{GPa}$ ) increased to $7 \mathrm{GPa}$ at the IMCs, which were consisted of $\mathrm{Al}_{2} \mathrm{Cu}, \mathrm{AlCu}, \mathrm{Al}_{3} \mathrm{Cu}_{4}$, and $\mathrm{Al}_{4} \mathrm{Cu}_{9}$. Figure 11 shows the tensile shear strengths for the different $\mathrm{Al} / \mathrm{Cu}$ joints. The error bars in the Figure 11 represent the range of the measured tensile shear strengths. In the cases of the 23/20, 23/28.6, 25/20, $25 / 28.6,25 / 40,27 / 28.6$, and $27 / 40$, an equivalent tensile shear strength (approximately $33.1 \mathrm{MPa}$ ) was obtained, and it was comparable to the tensile strength of the $\mathrm{Al}$ ribbon. This was because the fractures occurred at the $\mathrm{Al}$ ribbons instead of the $\mathrm{Al} / \mathrm{Cu}$ joints by the tensile shear tests. Figure 12a shows the result of tensile shear tests for the 23/20, verifying that the fracture occurred at the $\mathrm{Al}$ ribbons. However, relatively lower tensile shear strengths were measured for the 25/15.4, 27/20,29/20, and 29/40. For example, the average tensile shear strengths were found to be 21.5 and $16.0 \mathrm{MPa}$ for the $27 / 20$ and $29 / 20$, respectively. A significant decrease in the tensile shear strength was attributed to an application of large heat input or high laser power, which induced the formation of large IMCs region with cracks and voids (Figure 6). During the tensile shear tests, the crack initiation and propagation were likely to begin at the brittle IMCs and existing cracks and voids in the welding zones. As a result, the fractures occurred at the $\mathrm{Al} / \mathrm{Cu}$ joints, as shown in Figure 12b. Moreover, those specimens showed significantly large variations in the tensile shear strength values. For example, the range of tensile shear strength was 1.0 MPa for the $25 / 40$, and it increased to $8.5 \mathrm{MPa}$ for the $27 / 20$. This was because non- 
uniform welding quality was achieved even for the same experimental conditions due to the different formations of cracks and voids.

(a)
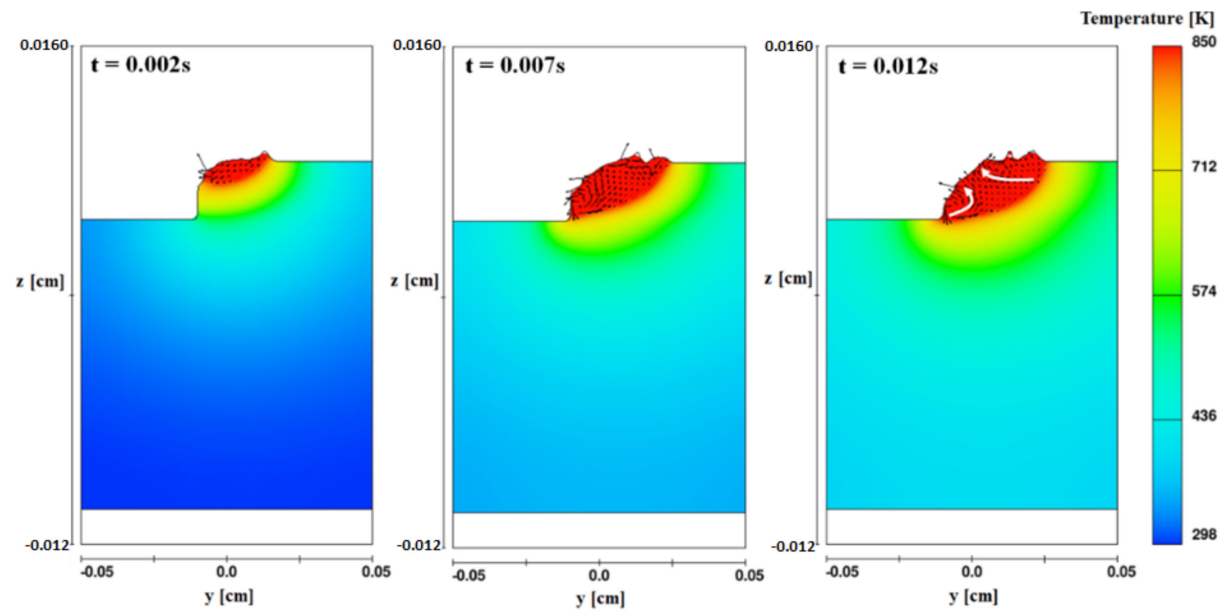

(b)
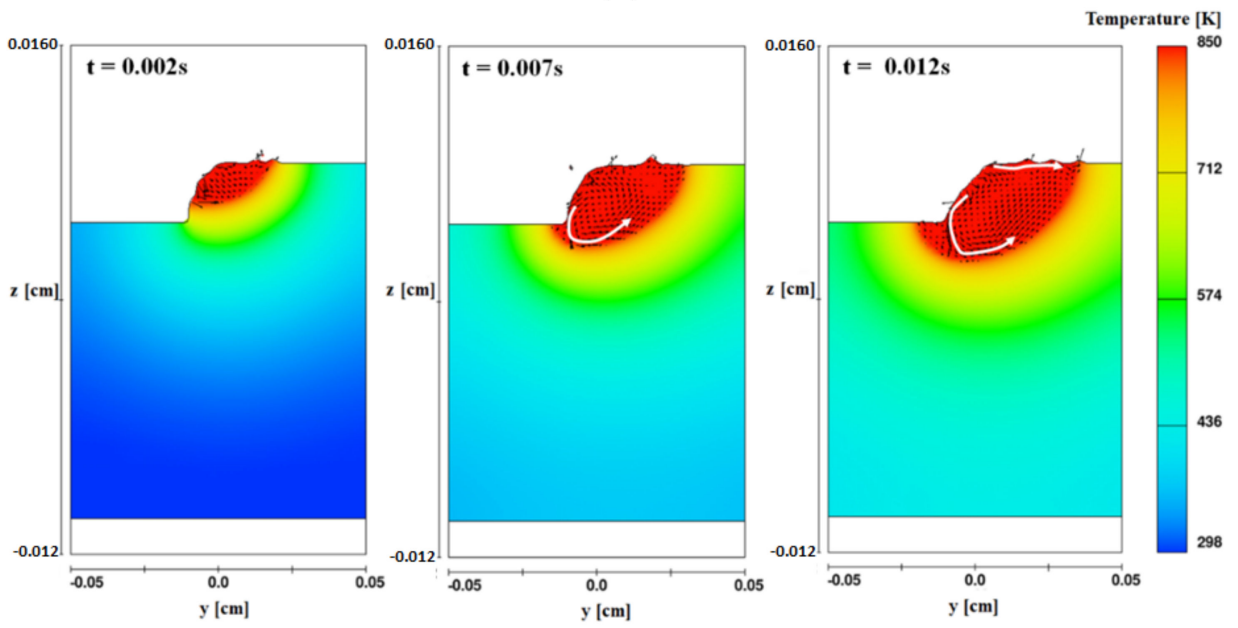

(c)
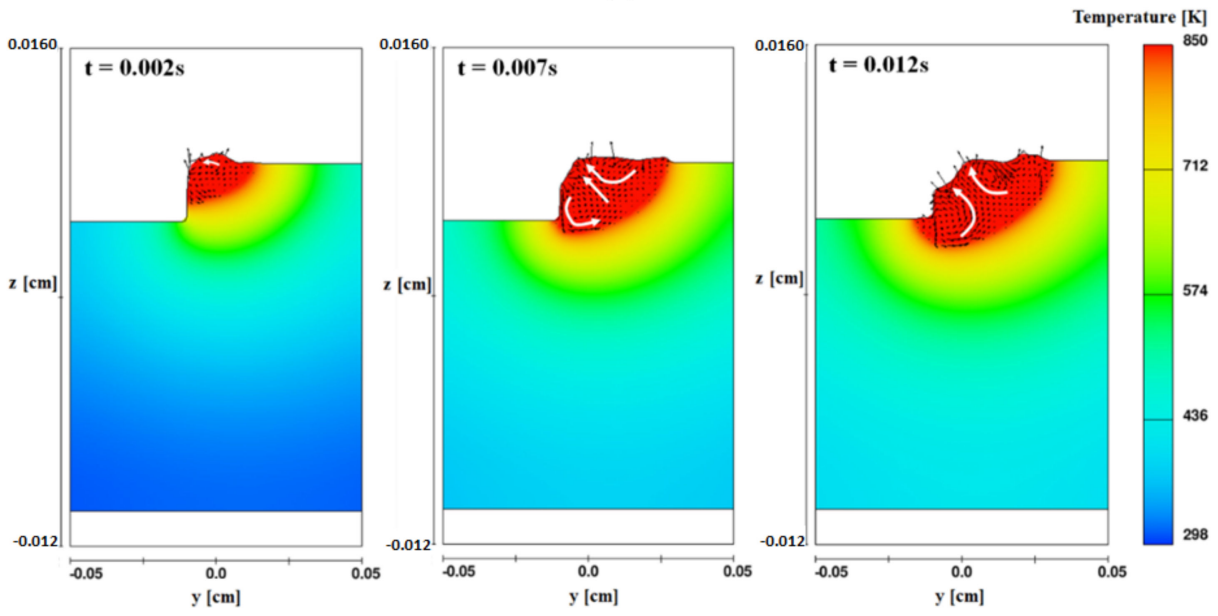

Figure 9. Cont. 
(d)
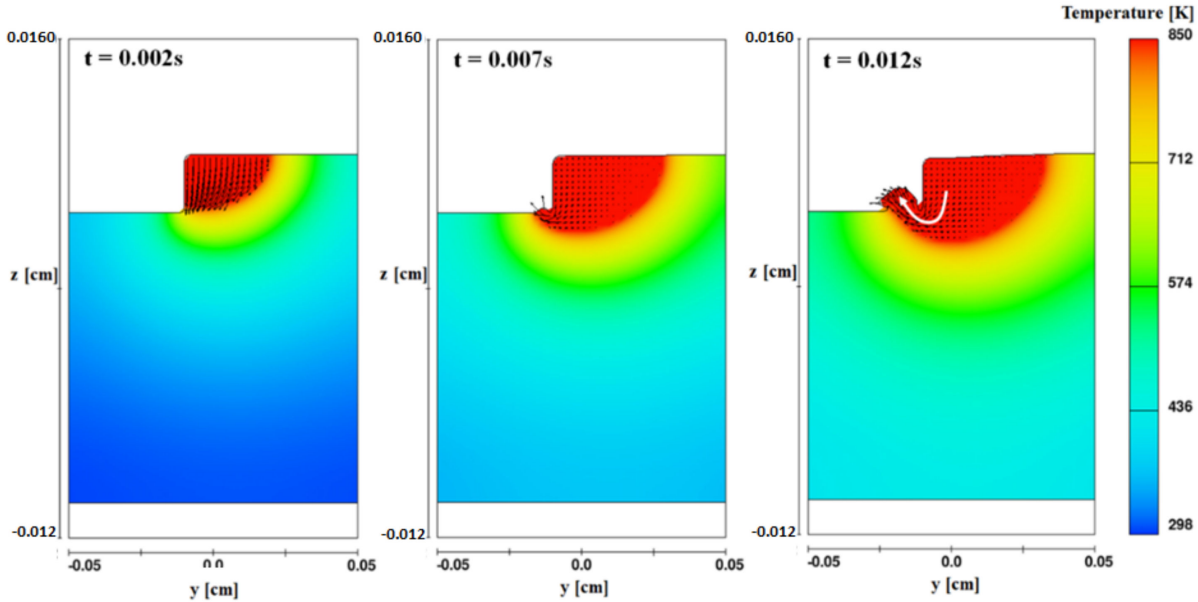

Figure 9. Temperature profiles and molten pool flow on transverse cross-section ( $y-z$ plane at $x=$ $1.23 \mathrm{~cm}$ ): (a) Negative surface tension gradient for the 23/20 (Case 1), (b) negative surface tension gradient for the 25/15.4 (Case 2), (c) positive surface tension gradient for the 25/15.4 (Case 3), and (d) without surface tension for the 25/15.4 (Case 4).

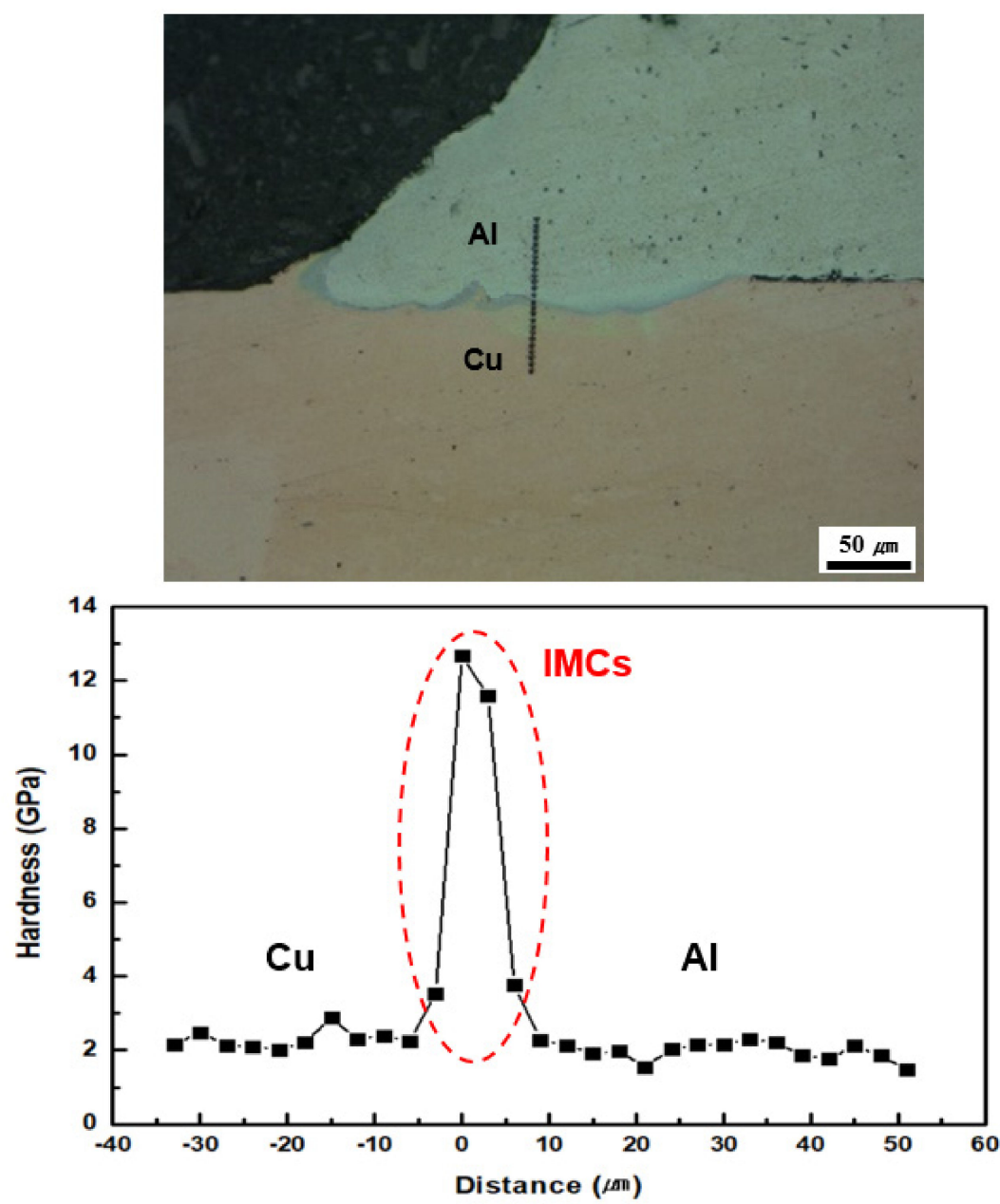

Figure 10. Measured microhardness as a function of the distance for the $23 / 20$.

Figure 13 shows the stress-strain curves obtained by the tensile shear tests for the 23/20, 25/15.4, 29/40, 27/20, and 29/20. Every Al/Cu joint showed similar elastic behaviors, while a large difference was observed in terms of the tensile shear strength and 
elongation. In the case of the $23 / 20$, the tensile shear strength and elongation were found to be $33.5 \mathrm{MPa}$ and $54.7 \%$, respectively. Similar stress-strain curves were obtained for the $23 / 28.6,25 / 20,25 / 28.6,25 / 40,27 / 28.6$, and $27 / 40$. However, significant decreases in the tensile shear strength and elongation were observed for the 25/15.4, 29/40,27/20, and $29 / 20$ in comparison with those of the $23 / 20$. For the $27 / 20$, the measured tensile shear strength was $21.9 \mathrm{MPa}$, and the elongation was $6.3 \%$. Solchenbach et al. [19] also reported that the existence of IMCs with cracks and voids at the $\mathrm{Al} / \mathrm{Cu}$ joints caused a significant decrease in the tensile shear strength.

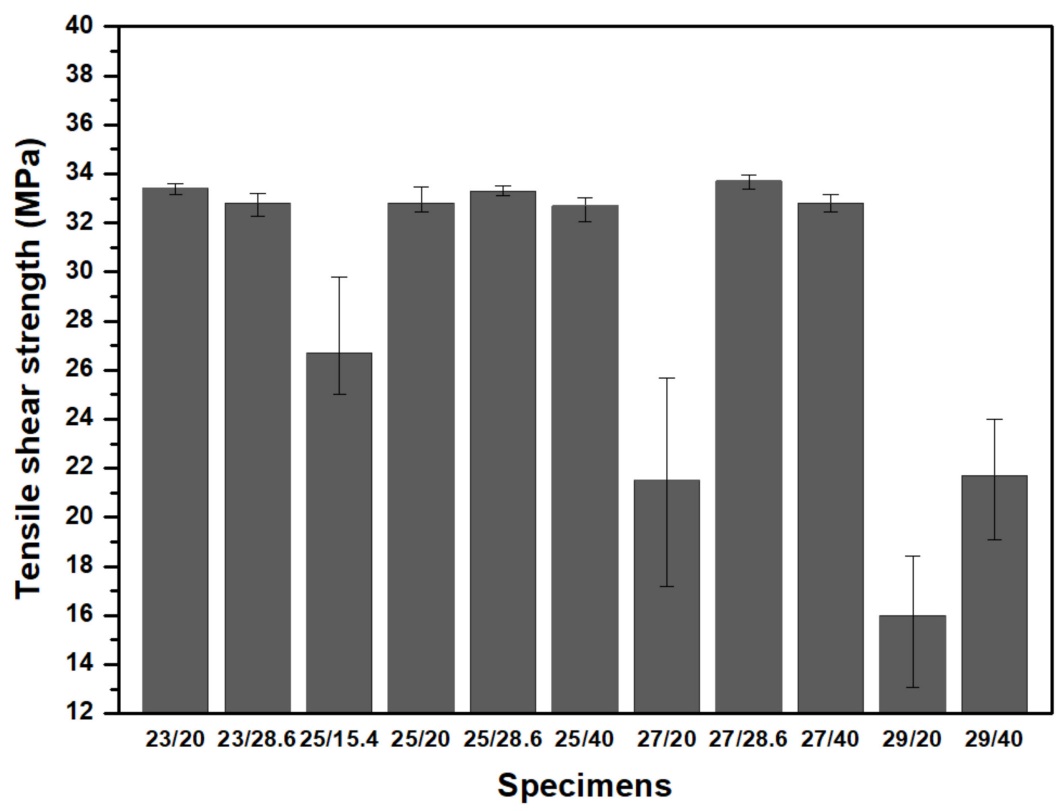

Figure 11. Measured tensile shear strength for the different $\mathrm{Al} / \mathrm{Cu}$ joints.

(a)

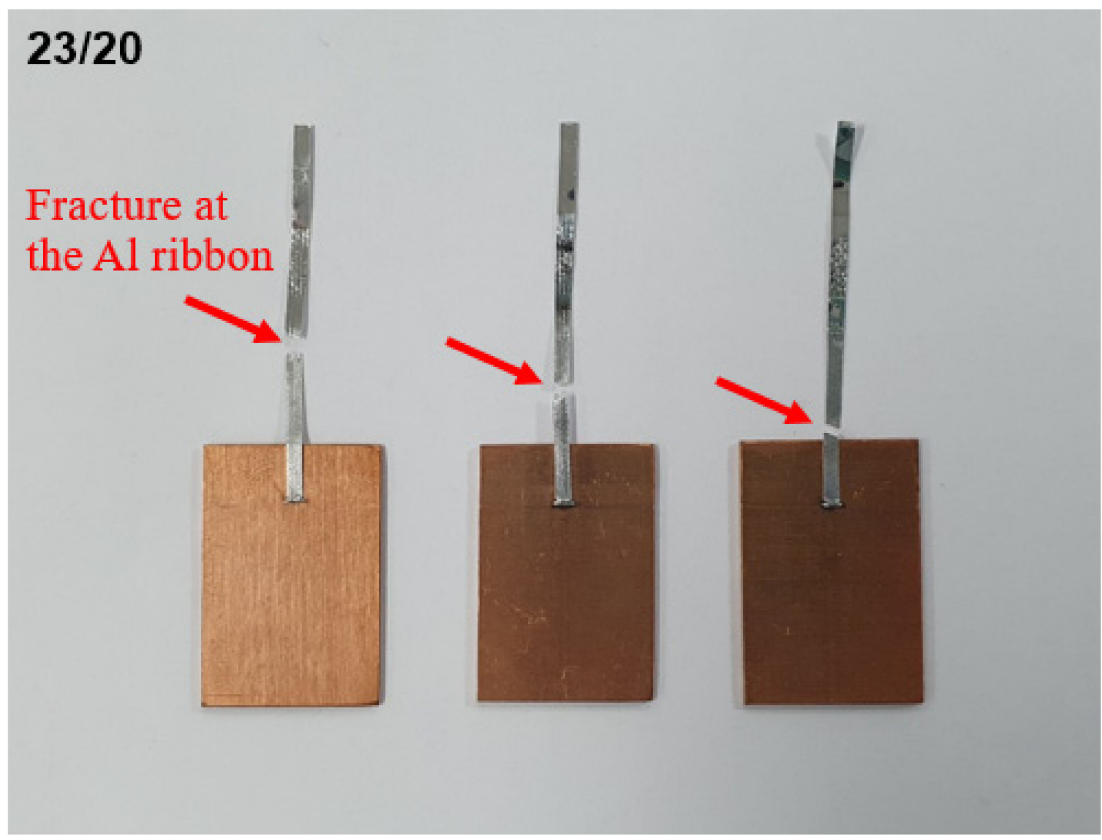

Figure 12. Cont. 
(b)

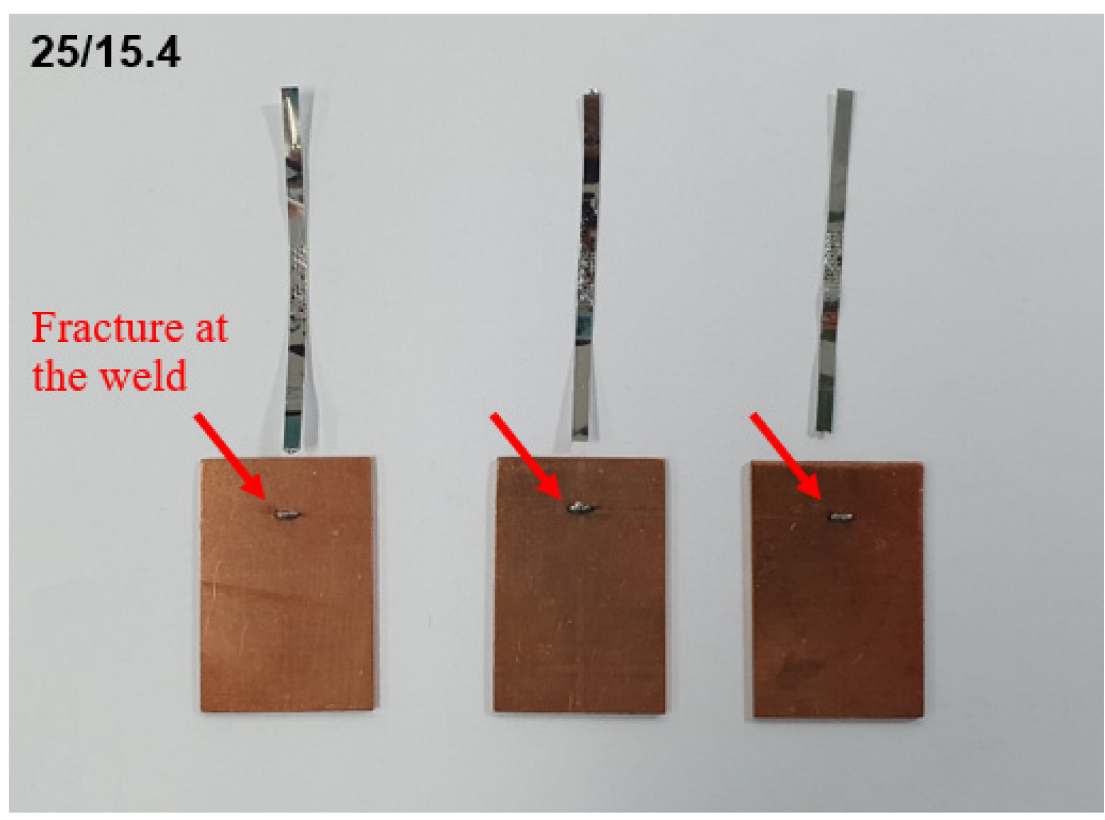

Figure 12. Results of the tensile shear tests for the (a) 23/20: fracture at the Al ribbon and (b) 25/15.4: fracture at the weld.

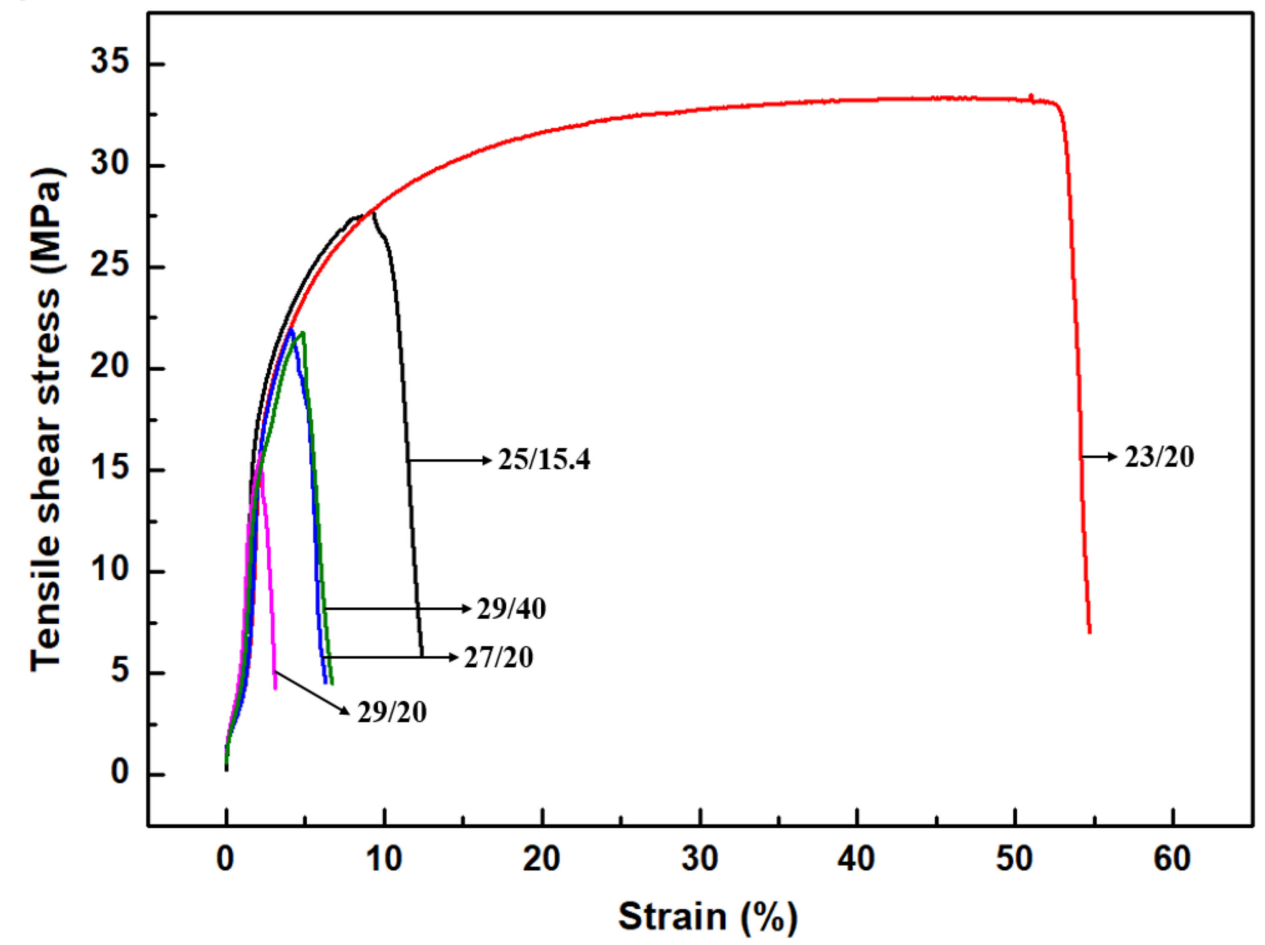

Figure 13. Stress-strain curves obtained by the tensile shear tests.

\subsection{Correlation between the Welding Area and Electrical and Mechanical Properties}

Figure 14a shows the measured welding area and electrical resistance for the various $\mathrm{Al} / \mathrm{Cu}$ joints. The error bars in the Figure 14 represent the range of the welding area and electrical resistance obtained by three times and five times of measurements, respectively. At the same scan speed, larger welding areas were created with an increase in the laser power. For example, at a scan speed of $20 \mathrm{~mm} / \mathrm{s}$, the welding area was found to be $0.140 \mathrm{~mm}^{2}$ with a laser power of $2300 \mathrm{~W}$. This value increased to $0.165,0.233$, and $0.248 \mathrm{~mm}^{2}$ 
as the laser power increased to 2500, 2700, and $2900 \mathrm{~W}$. Moreover, smaller welding areas were formed with an increase in the scan speed at the same laser power. At the laser power of $2500 \mathrm{~W}$, the welding area decreased from $0.208 \mathrm{~mm}^{2}$ to $0.165,0.146$, and $0.129 \mathrm{~mm}^{2}$ as the scan speed increased from $15.4 \mathrm{~mm}^{2}$ to $20,28.6$, and $40 \mathrm{~mm} / \mathrm{s}$. These results indicate that the welding area was strongly dependent on both the laser power and scan speed. In addition, a direct correlation was found between the welding area and electrical resistance, as shown in Figure 14a. The electrical resistance showed a similar trend to that of the welding area. The larger welding area of the $\mathrm{Al} / \mathrm{Cu}$ joints showed the higher electrical resistance. It is known that the $\mathrm{Al} / \mathrm{Cu}$ IMCs has higher electrical resistance than that of the base metals [15]. In this study, it was assumed that the electrical properties of $\mathrm{Al}$ and $\mathrm{Cu}$ were not changed during the laser welding process. Therefore, high electrical resistances with large welding areas were attributed to an extensive IMCs formation. In addition, an existence of cracks and voids at the welding area may also influence on the increase in electrical resistances. Figure $14 \mathrm{~b}$ shows the measured welding area and tensile shear strength of the different $\mathrm{Al} / \mathrm{Cu}$ joints. A strong correlation between the welding area and mechanical strength was found. The specimens with relatively small welding areas showed excellent tensile shear strength (i.e., 23/20, 23/28.6, 25/20, 25/28.6, 25/40, $27 / 28.6$, and $27 / 40$ ). For those specimens, the fracture occurred at the Al ribbons instead of the $\mathrm{Al} / \mathrm{Cu}$ joints by the tensile shear tests (Figure 12a). On the other hand, in the case of the $25 / 15.4,27 / 20,29 / 20$, and $29 / 40$, relatively large heat input and high laser power caused the formation of large welding area with cracks and voids, resulting in relatively low tensile shear strengths with the fracture occurrence at the $\mathrm{Al} / \mathrm{Cu}$ joints (Figure 12b). The results of the tensile shear strength, electrical resistance, and welding area are listed in Table 5. The formation of IMCs caused the deterioration of electrical conductivity and the brittle behavior of the $\mathrm{Al} / \mathrm{Cu}$ joints $[16,39,40]$. Therefore, the $\mathrm{Al} / \mathrm{Cu}$ joints with a minimum welding area were crucial to minimize the IMCs-induced side effects.

(a)

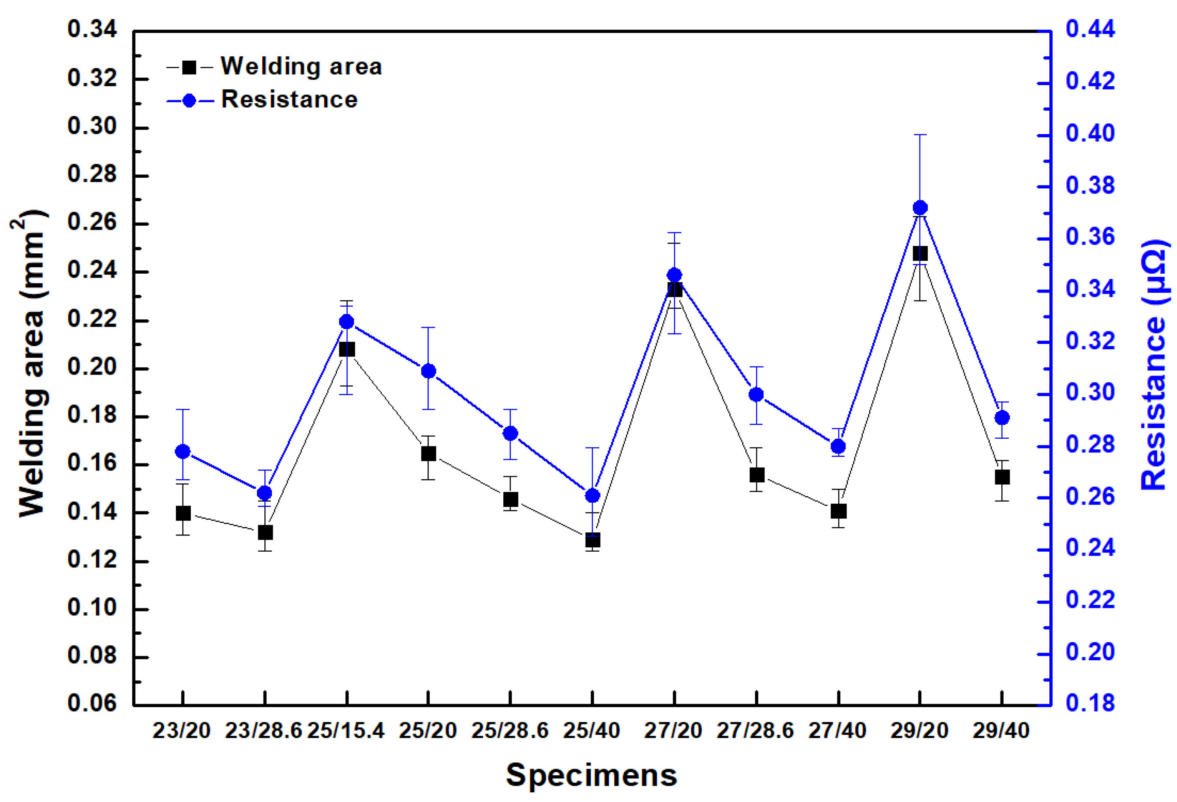

Figure 14. Cont. 
(b)

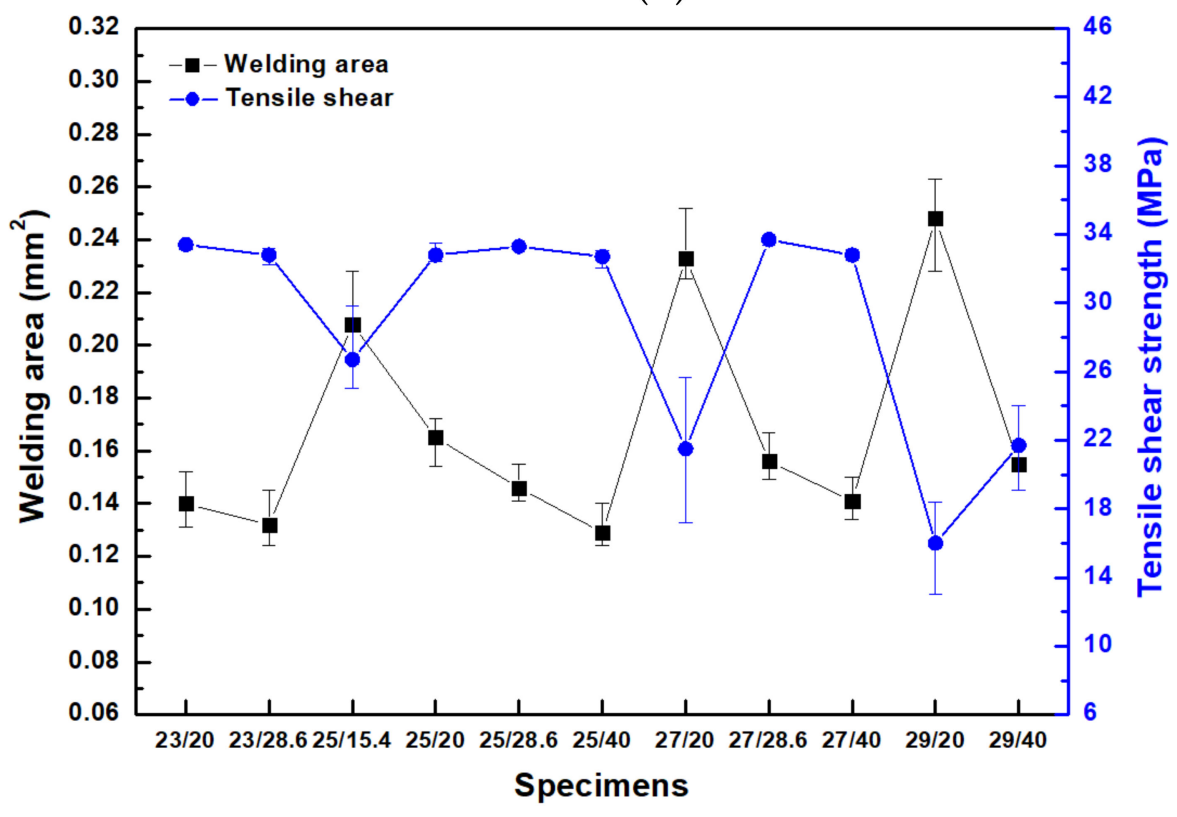

Figure 14. Correlation between (a) the welding area and electrical resistance and (b) the welding area and tensile shear strength for the different $\mathrm{Al} / \mathrm{Cu}$ joints.

Table 5. Results of the tensile shear strength, electrical resistance, and welding area for the different $\mathrm{Al} / \mathrm{Cu}$ joints.

\begin{tabular}{cccc}
\hline Specimens & $\begin{array}{c}\text { Tensile Shear } \\
\text { Strength }(\mathbf{M P a})\end{array}$ & $\begin{array}{c}\text { Electrical } \\
\text { Resistance }(\boldsymbol{\mu} \Omega)\end{array}$ & Welding Area $\left(\mathbf{m m}^{\mathbf{2}}\right)$ \\
\hline $23 / 20$ & 33.4 & 0.278 & 0.140 \\
$23 / 28.6$ & 32.8 & 0.262 & 0.132 \\
$25 / 15.4$ & 26.7 & 0.328 & 0.208 \\
$25 / 20$ & 32.8 & 0.309 & 0.165 \\
$25 / 28.6$ & 33.3 & 0.285 & 0.146 \\
$25 / 40$ & 32.7 & 0.261 & 0.129 \\
$27 / 20$ & 21.5 & 0.346 & 0.233 \\
$27 / 28.6$ & 33.7 & 0.300 & 0.156 \\
$27 / 40$ & 32.8 & 0.280 & 0.141 \\
$29 / 20$ & 16 & 0.372 & 0.248 \\
$29 / 40$ & 21.7 & 0.291 & 0.155 \\
\hline
\end{tabular}

\subsection{Development of Process Window}

The process window was developed for the dissimilar $\mathrm{Al} / \mathrm{Cu}$ laser welding in terms of laser power, scan speed, and heat input, as shown in Figure 15. The numbers near each data point in the Figure 15 indicate the calculated heat input for the corresponding experimental conditions. Moreover, the red polygon in the Figure 15 represents the process window for the $\mathrm{Al} / \mathrm{Cu}$ laser welding. The solid $\mathrm{Al} / \mathrm{Cu}$ joints with a defect-free weld and good mechanical strength were considered as the process window for the dissimilar $\mathrm{Al} / \mathrm{Cu}$ laser welding. The $\mathrm{Al} / \mathrm{Cu}$ joints with cracks and voids were excluded from the process window (i.e., specimens of 25/15.4, 27/20, 29/20, and 29/40). The experimental conditions for the process window were found to be in the range of 2300 to $2700 \mathrm{~W}$ for the laser power and 20 to $40 \mathrm{~mm} / \mathrm{s}$ for the scan speed. Moreover, the heat input should range from 62.5 to $125 \mathrm{~J} / \mathrm{mm}$. Even when the applied heat input ranged within the process window, if the applied laser power was lower than $2300 \mathrm{~W}$, the $\mathrm{Al} / \mathrm{Cu}$ laser welding failed because of the non-melting of the $\mathrm{Cu}$ sheet (marked with the blue-dotted circles for corresponding data points). On the contrary, the laser power greater than $2700 \mathrm{~W}$ with the applied heat input ranged within the process window led to the puckering at the weld, resulting in 
the formation of cracks and voids at the welding zone (marked with a blue circle for the corresponding data point). Moreover, the laser braze-welded $\mathrm{Al} / \mathrm{Cu}$ joints were marked with the green-dotted boxes, and those were expected to be the optimum experimental laser welding conditions for the $\mathrm{Al} / \mathrm{Cu}$ joints.

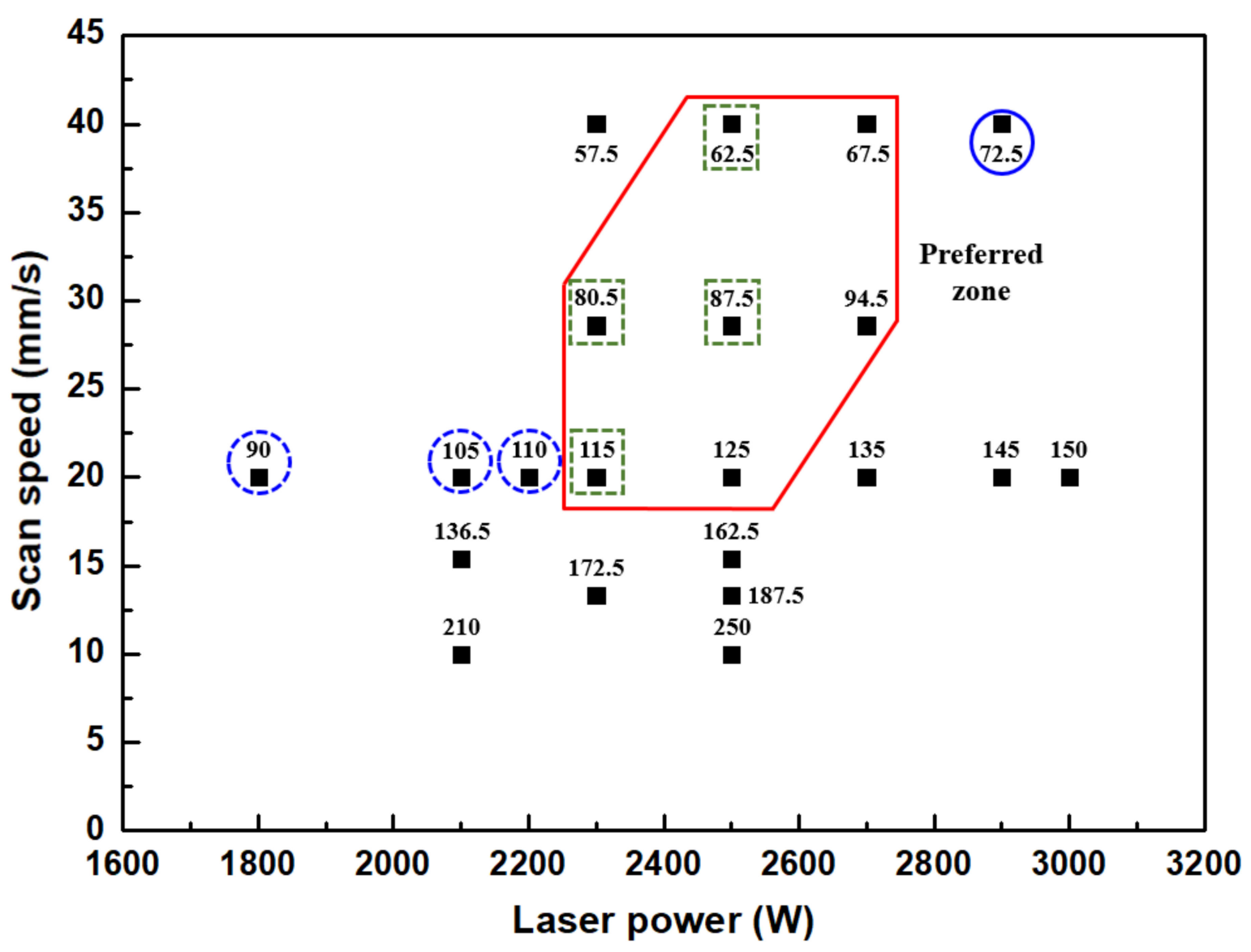

Figure 15. Developed process window for the dissimilar $\mathrm{Al} / \mathrm{Cu}$ laser welding.

\section{Conclusions}

In this study, the laser welding availability of $\mathrm{Al}$ ribbon (thickness: $0.2 \mathrm{~mm}$ ) to $\mathrm{Cu}$ sheet (thickness: $1 \mathrm{~mm}$ ) was investigated for the electrical connections. A pulsed fiber laser was used to achieve the solid $\mathrm{Al} / \mathrm{Cu}$ joints with different laser powers and scan speeds. The results can be summarized as follows.

1. Microstructure: The $\mathrm{Al} / \mathrm{Cu}$ intermetallic compounds were observed in the crosssectional SEM images and elemental distribution maps. Multiple cracks and voids were detected in the $\mathrm{Al} / \mathrm{Cu}$ joints of 25/15.4,27/20,29/20, and 29/40 owing to the application of high laser power or large heat input, while no weld defects were observed for the $\mathrm{Al} / \mathrm{Cu}$ joints of $23 / 20,23 / 28.6,25 / 20,25 / 28.6,25 / 40,27 / 28.6$, and 27/40. The EPMA and TEM analyses identified the developed intermetallic compounds at the $\mathrm{Al} / \mathrm{Cu}$ joints, which were confirmed to be $\mathrm{Al}_{4} \mathrm{Cu}_{9}, \mathrm{Al}_{2} \mathrm{Cu}, \mathrm{AlCu}$, etc. The numerical simulation confirmed that the large heat input caused the surface tension gradient-induced Marangoni flow at the molten pool, resulting in the turbulent mixture of $\mathrm{Al}$ and $\mathrm{Cu}$. Therefore, the complex swirl-like structures with various IMCs were developed at the $\mathrm{Al} / \mathrm{Cu}$ joints.

2. Correlation between the welding area and electrical and mechanical properties: Larger welding areas of the $\mathrm{Al} / \mathrm{Cu}$ joints were observed with increasing the laser power or decreasing the scan speed. Strong correlations were found between the electrical and mechanical properties and the welding area. Larger electrical resistances were measured with an increase in the welding area, while smaller mechanical strengths were obtained 
with increasing the welding area. This was because the welding area corresponded to the region of $\mathrm{Al} / \mathrm{Cu}$ intermetallic compounds, which have poor ductility and low mechanical strength with high electrical resistivity.

3. Process window: The process window was developed for the dissimilar $\mathrm{Al} / \mathrm{Cu}$ laser welding. To achieve the solid $\mathrm{Al} / \mathrm{Cu}$ joints with no weld defects, the experimental conditions were found to be in the range of $2300-2700 \mathrm{~W}$ for the laser power, $20-40 \mathrm{~mm} / \mathrm{s}$ for the scan speed, and 62.5-125 J/mm for the heat input, simultaneously. Moreover, laser braze-welded $\mathrm{Al} / \mathrm{Cu}$ joints with the excellent mechanical and electrical properties were achieved.

Author Contributions: Data curation, D.J. and J.O.K.; formal analysis, D.-W.C.; resources, J.O.K.; writing-original draft preparation, W.-S.S.; writing-review and editing, C.P.; supervision, Y.-J.K.; project administration, H.K. All authors have read and agreed to the published version of the manuscript.

Funding: This research was funded by the National Research Council of Science and Technology, Korea (project no. NK232A, 2021), the Korea Evaluation Institute of Industrial Technology, Korea (project no. 20015063, 2021-2023), and the Inha University research fund.

Data Availability Statement: The data presented in this study are available on request from the corresponding author. The data are not publicly available due to an ongoing study.

Conflicts of Interest: The authors declare no conflict of interest.

\section{References}

1. Schwartz, M.M.; Aircraft, S. Introduction to Brazing and Soldering. ASM Int. 2018, 6. [CrossRef]

2. Vianco, P.T. Corrosion issues in solder joint design and service. Weld. J. 1999, 78, 39-46.

3. Shi, Y.; Li, J.; Zhang, G.; Huang, J.; Gu, Y. Corrosion Behavior of Aluminum-Steel Weld-Brazing Joint. J. Mater. Eng. Perform. 2016, 25, 1916-1923. [CrossRef]

4. Harman, G.G. Wire Bonding in Microelectronics: Materials, Processes, Reliability and Yield, 3rd ed.; McGraw-Hill Education: New York, NY, USA, 2010; ISBN 9780071642651.

5. Aonuma, M.; Nakata, K. Dissimilar metal joining of ZK60 magnesium alloy and titanium by friction stir welding. Mater. Sci. Eng. B Solid State Mater. Adv. Technol. 2012, 177, 543-548. [CrossRef]

6. Sasaki, T.; Watanabe, T.; Hosokawa, Y.; Yanagisawa, A. Analysis for relative motion in ultrasonic welding of aluminium sheet. Sci. Technol. Weld. Jt. 2012, 18, 19-24. [CrossRef]

7. Maeda, M.; Sato, T.; Inoue, N.; Yagi, D.; Takahashi, Y. Anomalous microstructure formed at the interface between copper ribbon and tin-deposited copper plate by ultrasonic bonding. Microelectron. Reliab. 2011, 51, 130-136. [CrossRef]

8. Maeda, M.; Yagi, D.; Takahashi, Y. Interfacial microstructure between copper ribbon and nickel-coated copper plate formed by ultrasonic bonding. Q. J. Jpn. Weld. Soc. 2013, 31, 188-191. [CrossRef]

9. Sun, Z.; Ion, J.C. Laser welding of dissimilar metal combinations. J. Mater. Sci. 1995, 30, 4205-4214. [CrossRef]

10. Yan, S.; Hong, Z.; Watanabe, T.; Jingguo, T. CW/PW dual-beam YAG laser welding of steel/aluminum alloy sheets. Opt. Lasers Eng. 2010, 48, 732-736. [CrossRef]

11. Mehlmann, B.; Gehlen, E.; Olowinsky, A.; Gillner, A. Laser micro welding for ribbon bonding. Phys. Procedia 2014, 56, 776-781. [CrossRef]

12. Nwanoro, K.C.; Lu, H.; Yin, C.; Bailey, C. An analysis of the reliability and design optimization of aluminium ribbon bonds in power electronics modules using computer simulation method. Microelectron. Reliab. 2018, 87, 1-14. [CrossRef]

13. Li, H.; Cao, B.; Yang, J.W.; Liu, J. Modeling of resistance heat assisted ultrasonic welding of Cu-Al joint. J. Mater. Process. Technol. 2018, 256, 121-130. [CrossRef]

14. Davis, J.R. Copper and Copper Alloys. In ASM Speciality Handbook; ASM International: Almere, The Netherlands, 2001; ISBN 2001022956.

15. Rabkin, D.M.; Ryabov, V.R.; Lozovskaya, A.V.; Dovzhenko, V.A. Preparation and properties of copper-aluminum intermetallic compounds. Sov. Powder Metall. Met. Ceram. 1970, 9, 695-700. [CrossRef]

16. Chen, C.Y.; Chen, H.L.; Hwang, W.S. Influence of interfacial structure development on the fracture mechanism and bond strength of aluminum/copper bimetal plate. Mater. Trans. 2006, 47, 1232-1239. [CrossRef]

17. Schmidt, P.A.; Schweier, M.; Zaeh, M.F. Joining of lithium-ion batteries using laser beam welding: Electrical losses of welded aluminum and copper joints. J. Laser Appl. 2012, 915. [CrossRef]

18. Smith, S.; Blackburn, J.; Gittos, M.; De Bono, P.; Hilton, P. Welding of dissimilar metallic materials using a scanned laser beam. J. Laser Appl. 2013, 493. [CrossRef]

19. Solchenbach, T.; Plapper, P. Mechanical characteristics of laser braze-welded aluminium-copper connections. Opt. Laser Technol. 2013, 54, 249-256. [CrossRef] 
20. Kraetzsch, M.; Standfuss, J.; Klotzbach, A.; Kaspar, J.; Brenner, B.; Beyer, E. Laser Beam Welding with High-Frequency Beam Oscillation: Welding of Dissimilar Materials with Brilliant Fiber Lasers. Phys. Procedia 2011, 12, 142-149. [CrossRef]

21. Solchenbach, T.; Plapper, P.; Cai, W. Electrical performance of laser braze-welded aluminum-copper interconnects. J. Manuf. Process. 2014, 16, 183-189. [CrossRef]

22. Lee, S.J.; Nakamura, H.; Kawahito, Y.; Katayama, S. Effect of welding speed on microstructural and mechanical properties of laser lap weld joints in dissimilar Al and Cu sheets. Sci. Technol. Weld. Jt. 2014, 19, 111-118. [CrossRef]

23. Mai, T.A.; Spowage, A.C. Characterisation of dissimilar joints in laser welding of steel-kovar, copper-steel and copper-aluminium. Mater. Sci. Eng. A 2004, 374, 224-233. [CrossRef]

24. Zhang, G.; Takahashi, Y.; Heng, Z.; Takashima, K.; Misawa, K. Ultrasonic weldability of al ribbon to cu sheet and the dissimilar joint formation mode. Mater. Trans. 2015, 56, 1842-1851. [CrossRef]

25. Zhu, B.; Zhen, L.; Xia, H.; Su, J.; Niu, S.; Wu, L.; Tan, C.; Chen, B. Effect of the scanning path on the nanosecond pulse laser welded Al/Cu lapped joint. Opt. Laser Technol. 2021, 139, 106945. [CrossRef]

26. Kumar, A.; Gupta, M.P.; Banerjee, J.; Neogy, S.; Keskar, N.; Bhatt, R.B.; Behere, P.G.; Biswas, D.J. Micro-Welding of Stainless Steel and Copper Foils Using a Nano-Second Pulsed Fiber Laser. Lasers Manuf. Mater. Process. 2019, 6, 158-172. [CrossRef]

27. Trinh, L.N.; Lee, D. The Characteristics of Laser Welding of a Thin Aluminum Tab and Steel Battery Case for Lithium-Ion Battery. Metals 2020, 10, 842. [CrossRef]

28. Cho, D.W.; Park, J.H.; Moon, H.S. A study on molten pool behavior in the one pulse one drop GMAW process using computational fluid dynamics. Int. J. Heat Mass Transf. 2019, 139, 848-859. [CrossRef]

29. Cho, W.I.; Na, S.J.; Cho, M.H.; Lee, J.S. Numerical study of alloying element distribution in $\mathrm{CO}_{2}$ laser-GMA hybrid welding. Comput. Mater. Sci. 2010, 49, 792-800. [CrossRef]

30. Cho, D.W.; Kiran, D.V.; Na, S.J. Analysis of molten pool behavior by flux-wall guided metal transfer in low-current submerged arc welding process. Int. J. Heat Mass Transf. 2017, 110, 104-112. [CrossRef]

31. Cho, W.-I.; Na, S.-J. Impact of Wavelengths of CO2, Disk, and Green Lasers on Fusion Zone Shape in Laser Welding of Steel. J. Weld. Jt. 2020, 38, 235-240. [CrossRef]

32. Sim, A.; Chun, E.J.; Cho, D.W. Numerical Simulation of Surface Softening Behavior for Laser Heat Treated Cu-Bearing Medium Carbon Steel. Met. Mater. Int. 2020, 26, 1207-1217. [CrossRef]

33. Jarwitz, M.; Fetzer, F.; Weber, R.; Graf, T. Weld seam geometry and electrical resistance of laser-welded, aluminum-copper dissimilar joints produced with spatial beam oscillation. Metals 2018, 8, 510. [CrossRef]

34. Weigl, M.; Albert, F.; Schmidt, M. Enhancing the ductility of laser-welde copper-aluminum connections by using adapted filler materia. Phys. Procedia 2011, 12, 335-341. [CrossRef]

35. Chen, J.; Lai, Y.S.; Wang, Y.W.; Kao, C.R. Investigation of growth behavior of Al-Cu intermetallic compounds in Cu wire bonding. Microelectron. Reliab. 2011, 51, 125-129. [CrossRef]

36. Chen, H.; Yang, L.; Long, J. First-principles investigation of the elastic, Vickers hardness and thermodynamic properties of Al-Cu intermetallic compounds. Superlattices Microstruct. 2015, 79, 156-165. [CrossRef]

37. Liu, H.J.; Shen, J.J.; Zhou, L.; Zhao, Y.Q.; Liu, C.; Kuang, L.Y. Microstructural characterisation and mechanical properties of friction stir welded joints of aluminium alloy to copper. Sci. Technol. Weld. Jt. 2011, 16, 92-99. [CrossRef]

38. Hug, E.; Bellido, N. Brittleness study of intermetallic (Cu, Al) layers in copper-clad aluminium thin wires. Mater. Sci. Eng. A 2011, 528, 7103-7106. [CrossRef]

39. Braunović, M.; Alexandrov, N. Intermetallic Compounds At Aluminum-To-Copper Electrical Interfaces: Effect of Temperature And Electric Current. IEEE Trans. Compon. Packag. Manuf. Technol. Part A 1994, 17, 78-85. [CrossRef]

40. Lee, W.B.; Bang, K.S.; Jung, S.B. Effects of intermetallic compound on the electrical and mechanical properties of friction welded $\mathrm{Cu} / \mathrm{Al}$ bimetallic joints during annealing. J. Alloys Compd. 2005, 390, 212-219. [CrossRef] 